Supporting Information for

\title{
Precise Monitoring of Drug-Induced Kidney Injury Using an Endoplasmic Reticulum-Targetable Ratiometric Time-Gated Luminescence Probe for Superoxide Anions
}

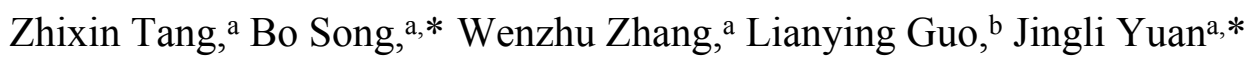

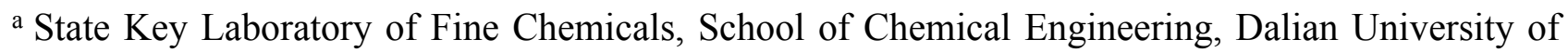
Technology, Dalian 116024, China

b Department of Pathophysiology, Dalian Medical University, Dalian 116044, P. R. China

*Corresponding authors.

Tel./Fax: +86-411-84986041;

E-mail: bo.song@dlut.edu.cn (B. Song); jlyuan@dlut.edu.cn (J. Yuan). 


\section{Table of Contents}

1. Experimental section

2. Characterization of the intermediate compounds and the ligand ER-NFTTA

3. Characterization of the products of ER-NFTTA $-\mathrm{Ln}^{3+}$ reacted with $\mathrm{O}_{2}{ }^{--}$

4. Effects of $\mathrm{pH}$ on luminescence response of the probe to $\mathrm{O}_{2}{ }^{\cdot-}$

5. Ratiometric time-gated luminescence imaging of $\mathrm{O}_{2}{ }^{--}$in live cells

6. Ratiometric luminescence imaging of $\mathrm{O}_{2}{ }^{--}$in drug-induced nephrotoxicity in mouse kidney

7. References 


\section{Experimental section}

\section{Materials and physical measurements}

The starting materials (compound $\mathbf{1}$ and compound $\mathbf{3}$, shown in Scheme S1) for the synthesis of the ligand, ER-NFTTA, were synthesized following the previous methods. ${ }^{1,2}$ Cisplatin, $\mathrm{KO}_{2}$, gentamicin $L$-carnitine, epigallocatechin-3-gallate, glucose and thapsigargin were purchased from Aladdin, China. Tunicamycin was purchased from Solarbio. Lipopolysaccharide (LPS) was purchased from Sigma-Aldrich. ER-Tracker Red was purchased from Nanjing KeyGen Biotech Co. Ltd. Blood urea nitrogen (BUN) and serum creatinine (SCr) Test Kits were purchased from Nanjing Jiancheng Bioengineering Institute. The isotonic saline solution consisting of $140 \mathrm{mM} \mathrm{NaCl}, 10$ $\mathrm{mM}$ glucose, and $3.5 \mathrm{mM} \mathrm{KCl}$ was prepared in our laboratory. Cultured HepG2 and HK-2 cells, and BALB/c mice were obtained from Dalian Medical University. Deionized distilled water was used throughout. Unless otherwise stated, all solvents and chemicals were purchased from commercial suppliers and were used without further purification.

${ }^{1} \mathrm{H}$ NMR and ${ }^{13} \mathrm{C}$ NMR spectra were measured on a Bruker Avance spectrometer (500 MHz for ${ }^{1} \mathrm{H}$ NMR and $125 \mathrm{MHz}$ for ${ }^{13} \mathrm{C}$ NMR). Mass spectra were measured on a HP1100 LC/MSD MS spectrometer. Elemental analysis was carried out on a Vario-EL analyzer. TGL spectra were measured on a Perkin Elmer LS 50B luminescence spectrometer with the settings of delay time, 0.2 ms; gate time, $0.4 \mathrm{~ms}$; cycle time, $20 \mathrm{~ms}$; excitation slit, $10 \mathrm{~nm}$; and emission slit, $10 \mathrm{~nm}$. Emission lifetimes were measured on a FS5 spectrofluorometer of Edinburgh Instruments. All TGL imaging measurements were carried out on a laboratory-use true color TGL microscope. ${ }^{3}$ Confocal fluorescence imaging measurements were carried out on an Olympus FV1000 confocal laser scanning microscope. The in vivo (organs and living mice) imaging was performed on a MesoQMR23-060H multifunctional in vivo imaging system (Molecular Devices, San Jose, USA).

\section{Synthesis of the ligand ER-NFTTA}

The reaction pathway for the synthesis of ER-NFTTA is illustrated in Scheme S1. 


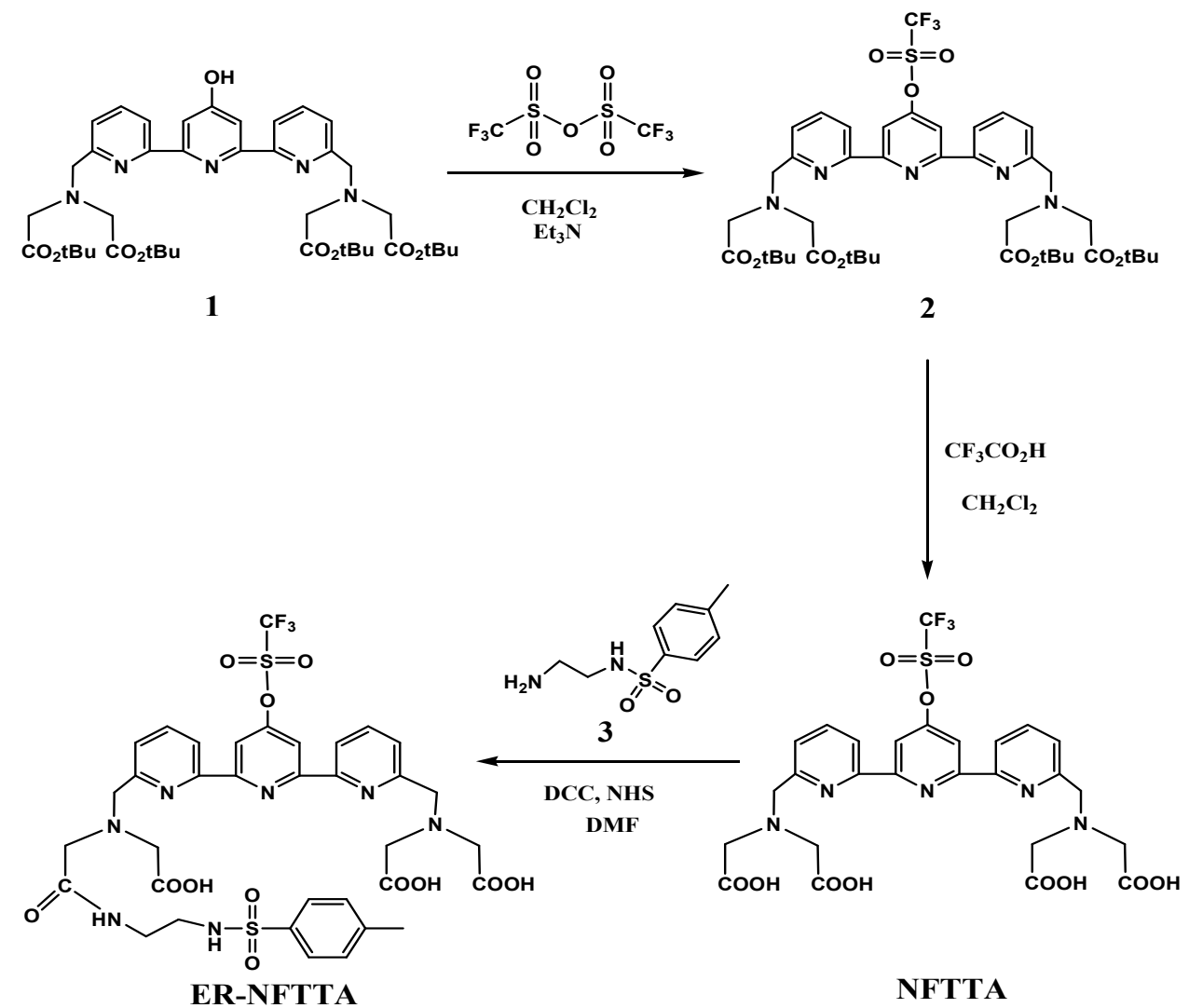

Scheme S1. Reaction pathway for the synthesis of ER-NFTTA.

Synthesis of compound 2. Compound $1(500 \mathrm{mg}, 0.655 \mathrm{mmol})$ and $3 \mathrm{~mL}$ of triethylamine were dissolved in $20 \mathrm{~mL}$ of anhydrous dichloromethane. A solution of trifluoromethanesulfonic anhydride $(370 \mathrm{mg}, 1.31 \mathrm{mmol})$ in anhydrous dichloromethane $(2 \mathrm{~mL})$ was added to the mixture dropwise at $-78{ }^{\circ} \mathrm{C}$ under nitrogen. Then the reaction mixture was stirred for $25 \mathrm{~min}$ at $-78{ }^{\circ} \mathrm{C}$ and $25 \mathrm{~min}$ at room temperature, respectively. The mixture was dilute with acetic ether, then washed with $1 \mathrm{M} \mathrm{HCl}$, water, and saturated $\mathrm{NaCl}$, respectively. The organic phase was dried with anhydrous $\mathrm{Na}_{2} \mathrm{SO}_{4}$. After filtration and evaporation, the crude product was purified by silica column, using ethyl acetate-petroleum ether $(1: 2, \mathrm{v} / \mathrm{v})$ as the eluent. Compound $\mathbf{2}$ was obtained as a yellow solid (370 mg, 41\%). ${ }^{1} \mathrm{H}$ NMR (500 MHz, $\left.\mathrm{CDCl}_{3}\right): \delta=8.41(\mathrm{~d}, J=10.0 \mathrm{~Hz}, 2 \mathrm{H}), 8.32(\mathrm{~s}, 2 \mathrm{H}), 7.78$ $(\mathrm{t}, J=10.0 \mathrm{~Hz}, 2 \mathrm{H}), 7.68(\mathrm{~d}, J=10.0 \mathrm{~Hz}, 2 \mathrm{H}), 4.06(\mathrm{~s}, 4 \mathrm{H}), 3.46(\mathrm{~s}, 8 \mathrm{H}), 1.39(\mathrm{~s}, 36 \mathrm{H}) .{ }^{13} \mathrm{C}$ NMR $\left(125 \mathrm{MHz}, \mathrm{CDCl}_{3}\right): \delta=169.54,158.29,157.95,157.37,152.29,136.59,118.71,111.79,80.05$, 58.72, 54.81, 27.14. ESI-MS (m/z): $896.20\left([\mathrm{M}+\mathrm{H}]^{+}\right)$.

Synthesis of NFTTA. Compound $2(370 \mathrm{mg}, 0.41 \mathrm{mmol})$ was dissolved in a mixture of $74 \mathrm{~mL}$ $\mathrm{CF}_{3} \mathrm{CO}_{2} \mathrm{H}-\mathrm{CH}_{2} \mathrm{Cl}_{2}(1: 1, \mathrm{v} / \mathrm{v})$. After the solution was stirred for $12 \mathrm{~h}$ at $25^{\circ} \mathrm{C}$, the solvent was evaporated. The residue was dissolved in $4.0 \mathrm{~mL}$ of methanol, and then $60 \mathrm{~mL}$ of diethyl ether was 
added to afford a white precipitate. After drying, the precipitate was added into $20 \mathrm{~mL}$ of dry acetonitrile, and the mixture was refluxed for $1 \mathrm{~h}$. The precipitate was collected by centrifugation and dried to afford NFTTA as a white solid (230 mg, 84\% yield). ${ }^{1} \mathrm{H}$ NMR (500 MHz, DMSO-d 6 ): $\delta$ $=8.56(\mathrm{~d}, J=5.0 \mathrm{~Hz}, 2 \mathrm{H}), 8.41(\mathrm{~s}, 2 \mathrm{H}), 8.06(\mathrm{t}, J=10.0 \mathrm{~Hz}, 2 \mathrm{H}), 7.72(\mathrm{~d}, J=5.0 \mathrm{~Hz}, 2 \mathrm{H}), 4.14(\mathrm{~s}$, 4H), $3.60(\mathrm{~s}, 8 \mathrm{H}) .{ }^{13} \mathrm{C}$ NMR (125 MHz, DMSO-d 6 ): $\delta=172.39,159.30,158.54,158.09,152.28$, 138.27, 124.35, 119.71, 112.36, 59.12, 54.36. ESI-MS (m/z): $670.17\left([\mathrm{M}-\mathrm{H}]^{-}\right), 334.70\left([\mathrm{M}-2 \mathrm{H}]^{2-}\right)$. Elemental analysis calcd (\%) for $\mathrm{C}_{26} \mathrm{H}_{24} \mathrm{~F}_{3} \mathrm{~N}_{5} \mathrm{O}_{11} \mathrm{~S} \cdot \mathrm{CF}_{3} \mathrm{COOH} \cdot \mathrm{CH}_{3} \mathrm{CN} \cdot \mathrm{H}_{2} \mathrm{O}$ (NFTTA $\cdot \mathrm{CF}_{3} \mathrm{COOH} \cdot \mathrm{CH}_{3} \mathrm{CN} \cdot \mathrm{H}_{2} \mathrm{O}$ ): C 42.66, H 3.58, N 9.95; found (\%): C 42.33, H 3.30, N 9.61.

Synthesis of ER-NFTTA. A mixture of NFTTA (230 mg, $0.343 \mathrm{mmol}$ ), dicyclohexylcarbodiimide (77.7 mg, $0.377 \mathrm{mmol})$, and N-hydroxysuccinimide (43.4 mg, $0.377 \mathrm{mmol})$ in $3 \mathrm{~mL}$ of anhydrous DMF was stirred for $24 \mathrm{~h}$ at room temperature. Then compound $3(80.7 \mathrm{mg}, 0.377 \mathrm{mmol})$ was added to the mixture, and the solution was stirred for another $6 \mathrm{~h}$ at room temperature. The solvent was evaporated, and the residue was carefully washed with THF, $\mathrm{CH}_{2} \mathrm{Cl}_{2}$, ethyl acetate, acetone and acetonitrile, respectively. Then the product was dissolved in $2.0 \mathrm{~mL}$ of methanol, and $50 \mathrm{~mL}$ of diethyl ether was added to afford a white precipitate, the precipitate was collected by centrifugation and dried to afford ER-NBTTA as a white powder (140 mg, 47.1\% yield). ${ }^{1} \mathrm{H}$ NMR (500 MHz, DMSO- $\left.\mathrm{d}_{6}\right): \delta=8.53(\mathrm{~d}, J=10.0 \mathrm{~Hz}, 2 \mathrm{H}), 8.41(\mathrm{~s}, 2 \mathrm{H}), 8.04(\mathrm{t}, J=10.0 \mathrm{~Hz}, 2 \mathrm{H}), 7.70(\mathrm{~d}, J=5.0 \mathrm{~Hz}$, $3 \mathrm{H}), 7.64(\mathrm{~d}, J=5.0 \mathrm{~Hz}, 2 \mathrm{H}), 7.43(\mathrm{~d}, J=5.0 \mathrm{~Hz}, 3 \mathrm{H}), 4.08(\mathrm{~s}, 4 \mathrm{H}), 3.49(\mathrm{~s}, 8 \mathrm{H}), 2.84-2.91(\mathrm{~m}, 4 \mathrm{H})$, 2.39 (s, 3H). ${ }^{13} \mathrm{C}$ NMR (126 MHz, DMSO-d 6 ): $\delta=172.99,159.40,158.54,158.09,152.33,143.06$, 138.24, 136.67, 129.76, 126.63, 124.16, 119.65, 112.37, 59.14, 55.73, 20.93. ESI-MS (m/z): 866.35 $\left([\mathrm{M}-\mathrm{H}]^{-}\right)$.

Synthesis of ER-HTTA. (4'-Hydroxy-2,2':6',2"-terpyridine-6,6"-diyl)bis(methylenenitrilo)tetrakis (aceticacid) (HTTA) was synthesized according to the previous method. ${ }^{4}$ ER-HTTA (shown in Scheme 1) was synthesized by following the same synthesis procedure of ER-NFTTA. ${ }^{1} \mathrm{H}$ NMR $\left(500 \mathrm{MHz}, \mathrm{DMSO}-\mathrm{d}_{6}\right): \delta=8.45(\mathrm{~d}, J=10.0 \mathrm{~Hz}, 2 \mathrm{H}), 8.07(\mathrm{~s}, 2 \mathrm{H}), 7.85(\mathrm{t}, J=10.0 \mathrm{~Hz}, 2 \mathrm{H}), 7.73(\mathrm{~d}$, $J=5.0 \mathrm{~Hz}, 3 \mathrm{H}), 7.62(\mathrm{~d}, J=5.0 \mathrm{~Hz}, 2 \mathrm{H}), 7.34(\mathrm{~d}, J=5.0 \mathrm{~Hz}, 3 \mathrm{H}), 4.08(\mathrm{~s}, 4 \mathrm{H}), 3.36(\mathrm{~s}, 8 \mathrm{H})$, 2.86-2.93 (m, 4H), $2.42(\mathrm{~s}, 3 \mathrm{H}) .{ }^{13} \mathrm{C}$ NMR (125 MHz, DMSO-d 6 ): $\delta=171.76,159.63,158.47$, $158.06,152.58,144.37,137.15,135.69,129.96,126.38,124.25,113.02,60.07,56.23,22.01$. $\operatorname{ESI-MS~(m/z):~} 734.23\left([\mathrm{M}-\mathrm{H}]^{-}\right)$.

Preparation of the stock solution of ER-NFTTA-Eu ${ }^{3+} / \mathbf{T b}^{3+}$ 
The stock solution of ER-NFTTA-Eu ${ }^{3+} / \mathrm{Tb}^{3+}\left(\mathrm{ER}-\mathrm{NFTTA} / \mathrm{Eu}^{3+} / \mathrm{Tb}^{3+}=2 / 1 / 1\right)$ was prepared by adding ER-NFTTA $(5.0 \mu \mathrm{mol}), \mathrm{EuCl}_{3} \cdot 6 \mathrm{H}_{2} \mathrm{O}(2.5 \mu \mathrm{mol})$ and $\mathrm{TbCl}_{3} \cdot 6 \mathrm{H}_{2} \mathrm{O}(2.5 \mu \mathrm{mol})$ into $5.0 \mathrm{~mL}$ of $10 \mathrm{mM}$ PBS buffer of $\mathrm{pH}$ 7.4. After stirring at room temperature for $30 \mathrm{~min}$, the obtained stock solution (total concentration of $\mathrm{Eu}^{3+}$ and $\mathrm{Tb}^{3+}$ complexes, $1.0 \mathrm{mM}$ ) was stored at $4{ }^{\circ} \mathrm{C}$, and suitably diluted with aqueous buffer before use.

\section{Reaction of ER-NFTTA-Eu ${ }^{3+} / \mathrm{Tb}^{3+}$ with $\mathrm{O}_{2}^{--}$and other reactive species}

The reactions of ER-NFTTA-Eu ${ }^{3+} / \mathrm{Tb}^{3+}\left(\right.$ ER-NFTTA/Eu $\left.{ }^{3+} / \mathrm{Tb}^{3+}=2 / 1 / 1, \mathrm{C}_{\text {total }}=5.0 \mu \mathrm{M}\right)$ with $\mathrm{O}_{2}{ }^{--}$and other reactive species, including GSH, Cys, Hcy, ascorbic acid (Vc), glucose, $\mathrm{H}_{2} \mathrm{~S}, \mathrm{H}_{2} \mathrm{O}_{2}$, $\mathrm{HClO}, \cdot \mathrm{OH}, \mathrm{NO}, \mathrm{ONOO}^{-},{ }^{1} \mathrm{O}_{2}$, were performed in $10 \mathrm{mM}$ PBS buffer at $\mathrm{pH}$ 7.4. After the probe solution was incubated with these species for $40 \mathrm{~min}$, respectively, the time-gated emission spectra of the solutions were measured on a Perkin Elmer LS 50B luminescence spectrometer with the settings of delay time, $0.2 \mathrm{~ms}$; gate time, $0.4 \mathrm{~ms}$; cycle time, $20 \mathrm{~ms}$; excitation slit, $10 \mathrm{~nm}$; and emission slit, $10 \mathrm{~nm}$.

\section{MTT assay}

Before the probe ER-NFTTA- $\mathrm{Ln}^{3+}$ was used for bioimaging, the cytotoxicity of ER-NFTTA- $\mathrm{Ln}^{3+}$ to HepG2 cells was measured by the MTT test using the previously reported method. ${ }^{5}$ HepG2 cells were washed with an isotonic saline solution, and then incubated with different concentrations of ER-NFTTA-Ln ${ }^{3+}(0,100,200$ and $300 \mu \mathrm{M})$ for $24 \mathrm{~h}$ at $37{ }^{\circ} \mathrm{C}$ in a $5 \% \mathrm{CO}_{2} / 95 \%$ air incubator. After the probe was removed, the cells were further incubated with the isotonic saline solution containing $500 \mu \mathrm{g} \mathrm{ml}^{-1}$ of MTT for $4 \mathrm{~h}$ in the incubator. After the supernatants were removed, the cells were dissolved in DMSO, and then the absorbance at $490 \mathrm{~nm}$ was measured.

\section{Co-localization experiments}

After HepG2 cells were incubated with tunicamycin (Tm, $100 \mu \mathrm{g} / \mathrm{mL}$ ) for $4 \mathrm{~h}$ at $37^{\circ} \mathrm{C}$, the cells were washed three times with isotonic saline solution, and then incubated with isotonic saline solution containing $100 \mu \mathrm{M}$ of ER-NFTTA-Tb ${ }^{3+}\left(\right.$ ER-NFTTA/Eu $\left.{ }^{3+} / \mathrm{Tb}^{3+}=2 / 1 / 1\right)$ for another $2 \mathrm{~h}$. The cells were washed, and then further incubated with ER-Tracker Red (100 nM) for $40 \mathrm{~min}$. After 
washing with isotonic saline solution, the cells were subjected to the confocal fluorescence imaging measurements.

\section{In vivo distribution and toxicity evaluations}

To evaluate the in vivo distribution of the probe, the BALB/c mice were intravenously injected with ER-NFTTA-Eu ${ }^{3+}(100 \mu \mathrm{L}$ in physiological saline, $500 \mu \mathrm{M})$ and sacrificed by dislocating cervical vertebra at $2 \mathrm{~h}$ post-injection. Several main organs were harvested from the mice and their luminescence images were recorded on an in vivo luminescence imaging system using a $365 \mathrm{~nm}$ excitation light and an emission filter, $630 \pm 75 \mathrm{~nm}$.

To further examine the biocompatibility of ER-NFTTA-Eu ${ }^{3+} / \mathrm{Tb}^{3+}$, the BALB/c mice were injected with $100 \mu \mathrm{L}$ physiological saline solution containing ER-NFTTA-Eu ${ }^{3+} / \mathrm{Tb}^{3+}(500 \mu \mathrm{M}$, ER-NFTTA/Eu $\left.{ }^{3+} / \mathrm{Tb}^{3+}=2 / 1 / 1\right)$. After $24 \mathrm{~h}$, the main organs (heart, liver, spleen, lung, and kidney) were surgically dissected and fixed with 4\% formaldehyde in PBS and embedded in paraffin. Then the standard hematoxylin and eosin (H\&E) staining was carried out for histological analysis.

To evaluate the hepatobiliary clearance efficiency and renal clearance efficiency to the probe, the BALB/c mice were injected with $100 \mu \mathrm{L}$ physiological saline solution containing ER-NFTTA-Eu ${ }^{3+}$ (100 $\mu \mathrm{L}$ in physiological saline, $500 \mu \mathrm{M})$. After injection of the probe over different time periods, the livers and kidneys of mice were surgically dissected, homogenized in PBS (10 mM, pH 7.4) and centrifuged at 4,500 rpm for $15 \mathrm{~min}$ to remove insoluble components. The TGL intensities of the final supernatants were measured on the luminescence spectrometer.

\section{Visualization of the protective effects of LC and EGCG against drug-induced nephrotoxicity}

For investigating the protective effects of L-carnitine (LC) and epigallocatechin-3-gallate (EGCG) against cisplatin- and gentamicin-induced acute kidney injury, the BALB/c mice were divided into four groups. For the negative control group, the mice were given physiological saline $(300 \mu \mathrm{L})$ in the peritoneal cavity. After $48 \mathrm{~h}$, ER-NFTTA-Eu ${ }^{3+} / \mathrm{Tb}^{3+}\left(\mathrm{ER}-\mathrm{NFTTA} / \mathrm{Eu}^{3+} / \mathrm{Tb}^{3+}=\right.$ 2/1/1, $100 \mu \mathrm{L}$ in physiological saline, $500 \mu \mathrm{M}$ ) was intravenously injected for $2 \mathrm{~h}$. The mice in second group were given an intraperitoneal injection of cisplatin $(300 \mu \mathrm{L}$ in physiological saline, 20 $\mathrm{mg} / \mathrm{kg}$ ) or gentamicin $(300 \mu \mathrm{L}$ in physiological saline, $100 \mathrm{mg} / \mathrm{kg})$ and stimulated for $48 \mathrm{~h}$ or $72 \mathrm{~h}$, respectively, followed by intravenous injection with the probe ER-NFTTA-Eu ${ }^{3+} / \mathrm{Tb}^{3+}$ 
(ER-NFTTA/Eu ${ }^{3+} / \mathrm{Tb}^{3+}=2 / 1 / 1,100 \mu \mathrm{L}$ in physiological saline, $500 \mu \mathrm{M}$ ) for $2 \mathrm{~h}$. The mice in third group were intraperitoneally pre-injected with LC (100 $\mu \mathrm{L}$ in physiological saline, $400 \mathrm{mg} / \mathrm{kg})$ for $12 \mathrm{~h}$. Then the mice were injected intraperitoneally with cisplatin $(300 \mu \mathrm{L}$ in physiological saline, $20 \mathrm{mg} / \mathrm{kg}$ ) for $48 \mathrm{~h}$ or gentamicin $(300 \mu \mathrm{L}$ in physiological saline, $100 \mathrm{mg} / \mathrm{kg}$ ) for $72 \mathrm{~h}$, and followed by intravenous injection with the same dose of the probe for $2 \mathrm{~h}$. The mice in fourth group were pre-injected intraperitoneally with EGCG $(100 \mu \mathrm{L}$ in physiological saline, $400 \mathrm{mg} / \mathrm{kg})$ for 12 h. Then the mice were injected intraperitoneally with cisplatin $(300 \mu \mathrm{L}$ in physiological saline, 20 $\mathrm{mg} / \mathrm{kg}$ ) for $48 \mathrm{~h}$ or gentamicin $(300 \mu \mathrm{L}$ in physiological saline, $100 \mathrm{mg} / \mathrm{kg}$ ) for $72 \mathrm{~h}$, and followed by intravenous injection with the same dose of the probe for $2 \mathrm{~h}$. All of the mice sacrificed by dislocating cervical vertebra and their kidneys were dissected for imaging on a Multi-functional in vivo imaging system (Molecular Devices, San Jose, CA. USA) under $365 \mathrm{~nm}$ excitation (for green luminescence signals: emission filter, $525 \pm 50 \mathrm{~nm}$; for red luminescence signals: emission filter, $630 \pm 75 \mathrm{~nm}$ ). Meanwhile, the above collected kidneys were cryosectioned by microtome at $-20{ }^{\circ} \mathrm{C}$ into slices of $15 \mu \mathrm{m}$ thicknesses and were subjected to the time-gated luminescence imaging measurements on the microscope (excitation filter, 330-380 nm; dichroicmirror, $400 \mathrm{~nm}$; two emission filters, BP $540 \pm 25 \mathrm{~nm}$ for $\mathrm{Tb}^{3+}$ emission and $\mathrm{LP}>590 \mathrm{~nm}$ for $\mathrm{Eu}^{3+}$ emission), with the conditions of delay time, $33 \mu \mathrm{s}$; gate time, $1.0 \mathrm{~ms}$; lamp pulse width, $80 \mu \mathrm{s}$; and exposure time, 4.2 s.

\section{Luminescence imaging of $\mathrm{O}_{2}^{--}$in LPS-induced inflammation of mice}

Lipopolysaccharide (LPS, $50 \mu \mathrm{L}$ in physiological saline, $10.0 \mathrm{mg} / \mathrm{mL}$ ) and physiological saline $(50 \mu \mathrm{L})$ were correspondingly injected into the left and right (the control) tibiotarsal joints of 6-8 week-old BALB/c nude mice ( 20 g bodyweight) to induce acute inflammation. After injection of LPS for $5 \mathrm{~h}$, the left and right tibiotarsal joints of BALB/c nude mice were injected with $50 \mu \mathrm{L}$ physiological saline solution containing ER-NFTTA-Eu ${ }^{3+} / \mathrm{Tb}^{3+}\left(500 \mu \mathrm{M}\right.$, ER-NFTTA/Eu ${ }^{3+} / \mathrm{Tb}^{3+}=$ 2/1/1). After $1.5 \mathrm{~h}$, the mice were anesthetized with $3.6 \%$ chloral hydrate and placed into the imaging chamber for luminescence imaging. Whole body luminescence images were recorded on a MesoQMR23-060H multifunctional in vivo imaging system (Molecular Devices, San Jose, CA. U.S.A.). Green luminescence: emission filter, $525 \pm 50 \mathrm{~nm}$; red luminescence: emission filter, $630 \pm$ $75 \mathrm{~nm}$; excitation wavelength, $365 \mathrm{~nm}$. 


\section{Statistical analysis}

All the experiments were performed three times and the values are presented as the mean $\pm \mathrm{SD}$. Statistical comparison between two groups was determined by Student's test. All statistical analyses were conducted with Excel $\left({ }^{*} P<0.05,{ }^{* *} P<0.01,{ }^{* * *} P<0.001\right)$. A value of $P<0.05$ was considered statistically significant.

\section{Characterization of the intermediate compounds and the ligand ER-NFTTA}

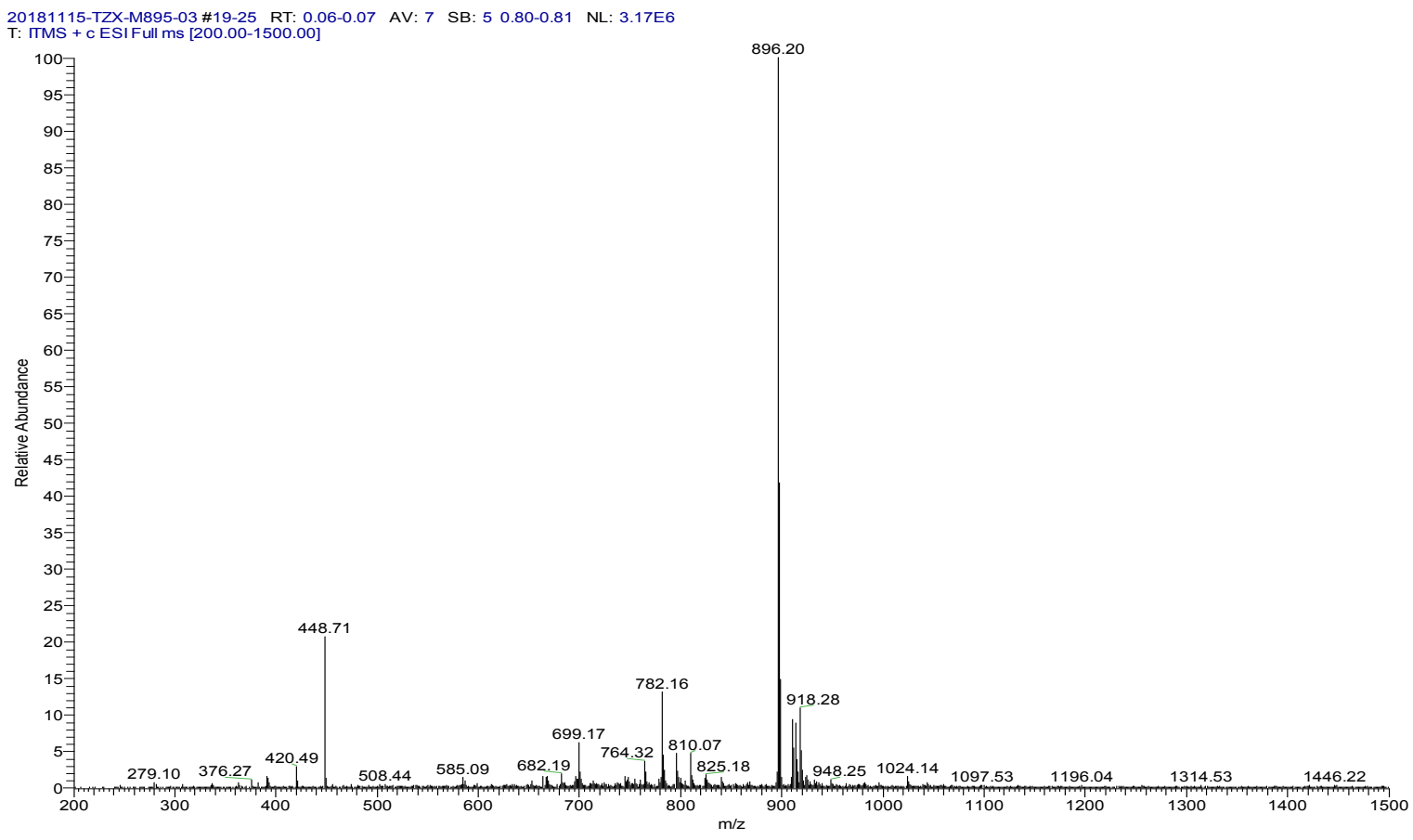

Figure S1. ESI-MS of compound 2. 


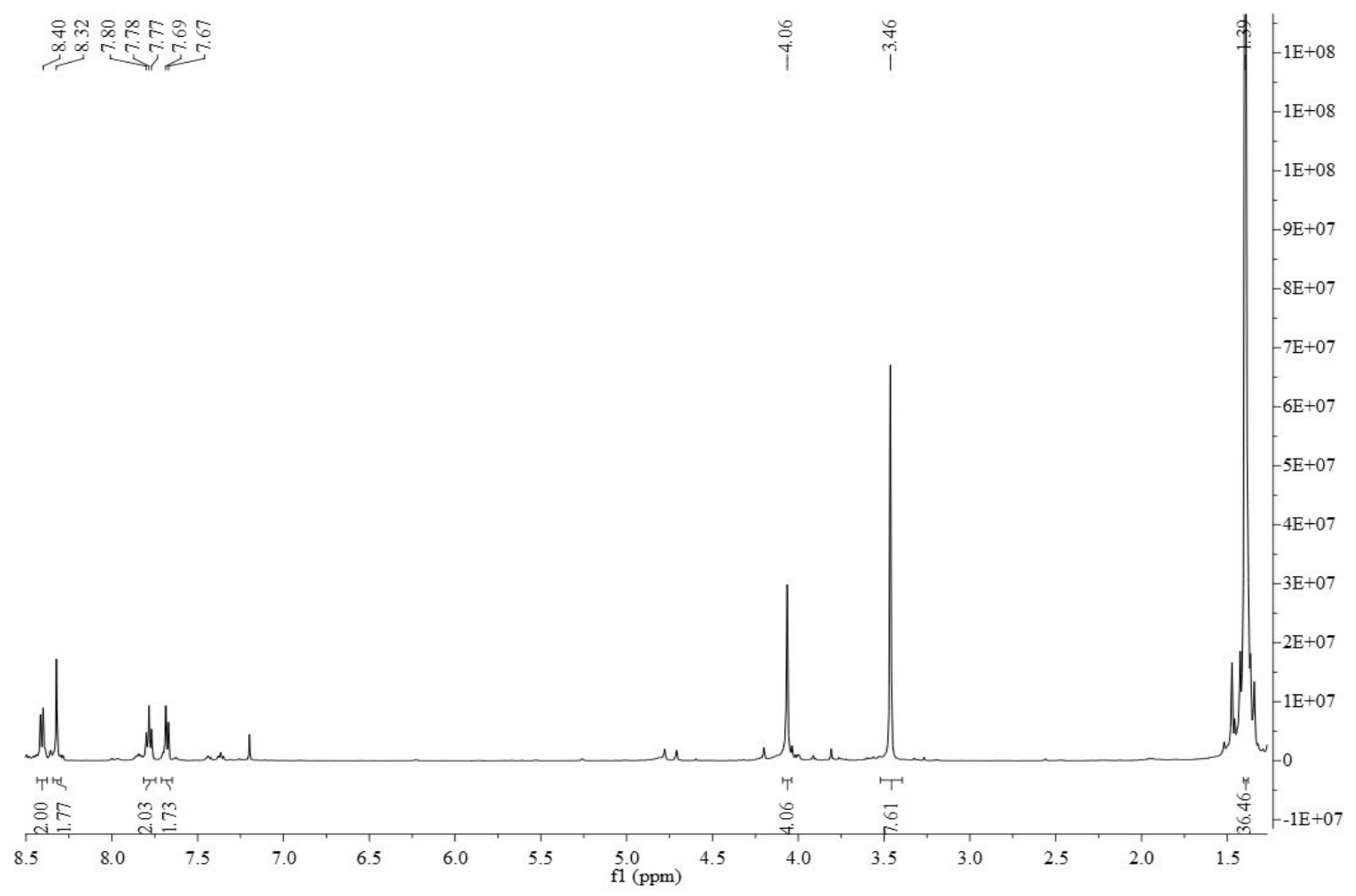

Figure S2. ${ }^{1} \mathrm{H}$ NMR spectrum of compound $2\left(\mathrm{CDCl}_{3}\right)$.

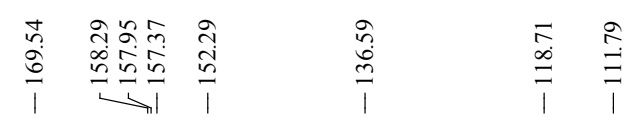

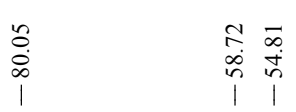

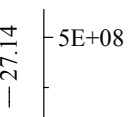
$-4 \mathrm{E}+08$

$4 \mathrm{E}+08$

$\mathrm{E}+08$

$2 \mathrm{E}+08$

$2 \mathrm{E}+08$

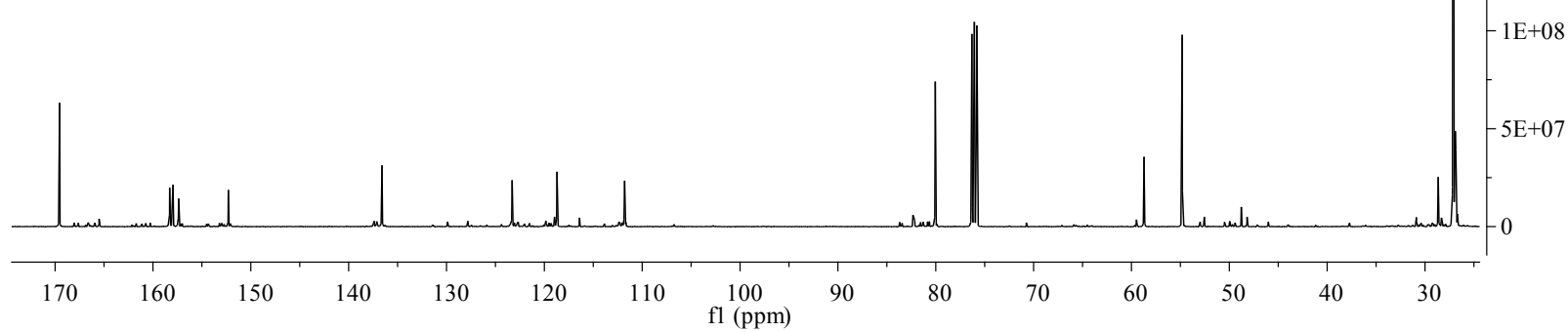

Figure S3. ${ }^{13} \mathrm{C}$ NMR spectrum of compound $2\left(\mathrm{CDCl}_{3}\right)$. 
20181119-TZX-M671 \#20-22 RT: 0.06-0.06 AV: 3 SB: 3 0.02-0.03 NL: $8.87 E 6$ T: TMS - c ESI Full ms [120.00-1000.00]

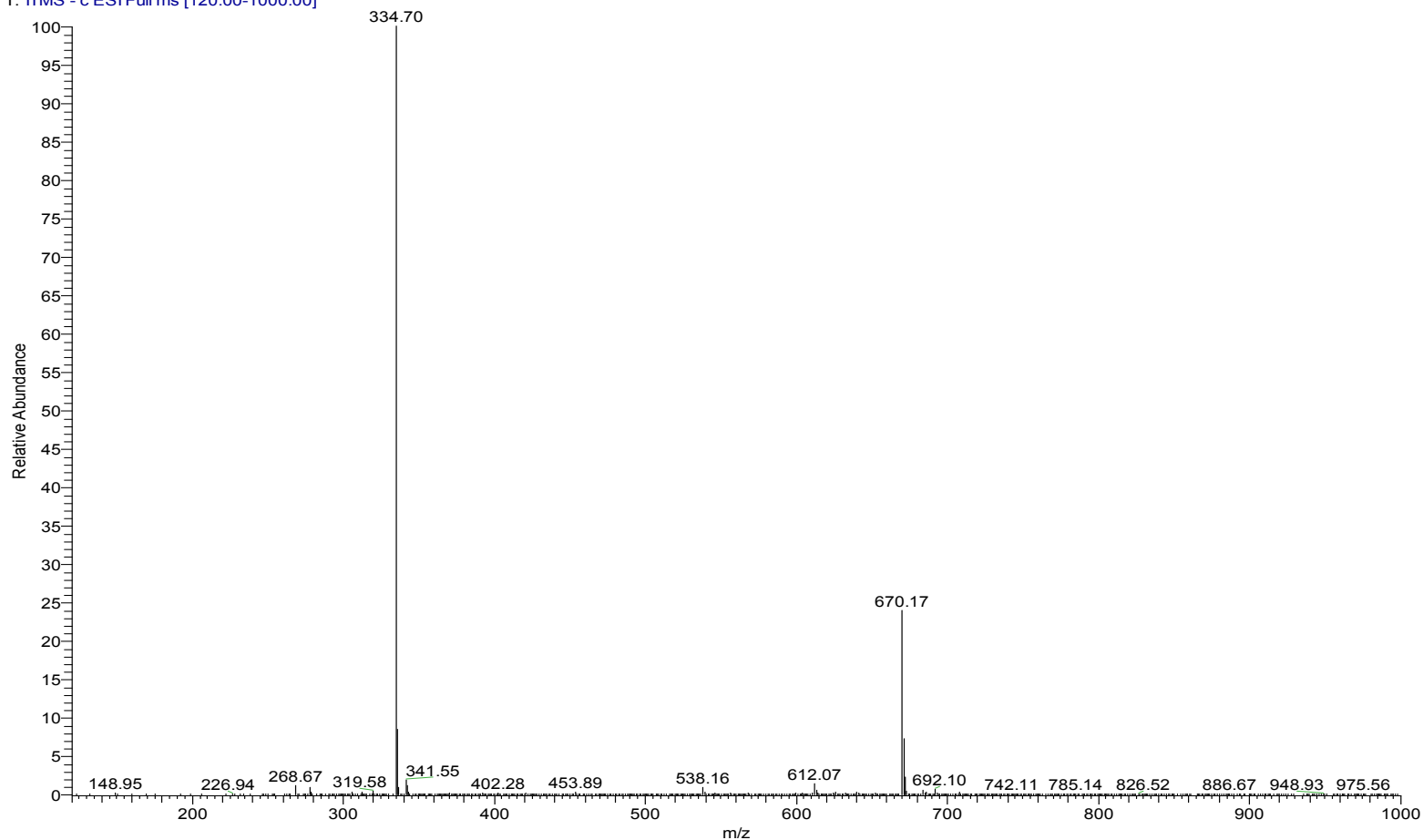

Figure S4. ESI-MS of NFTTA.

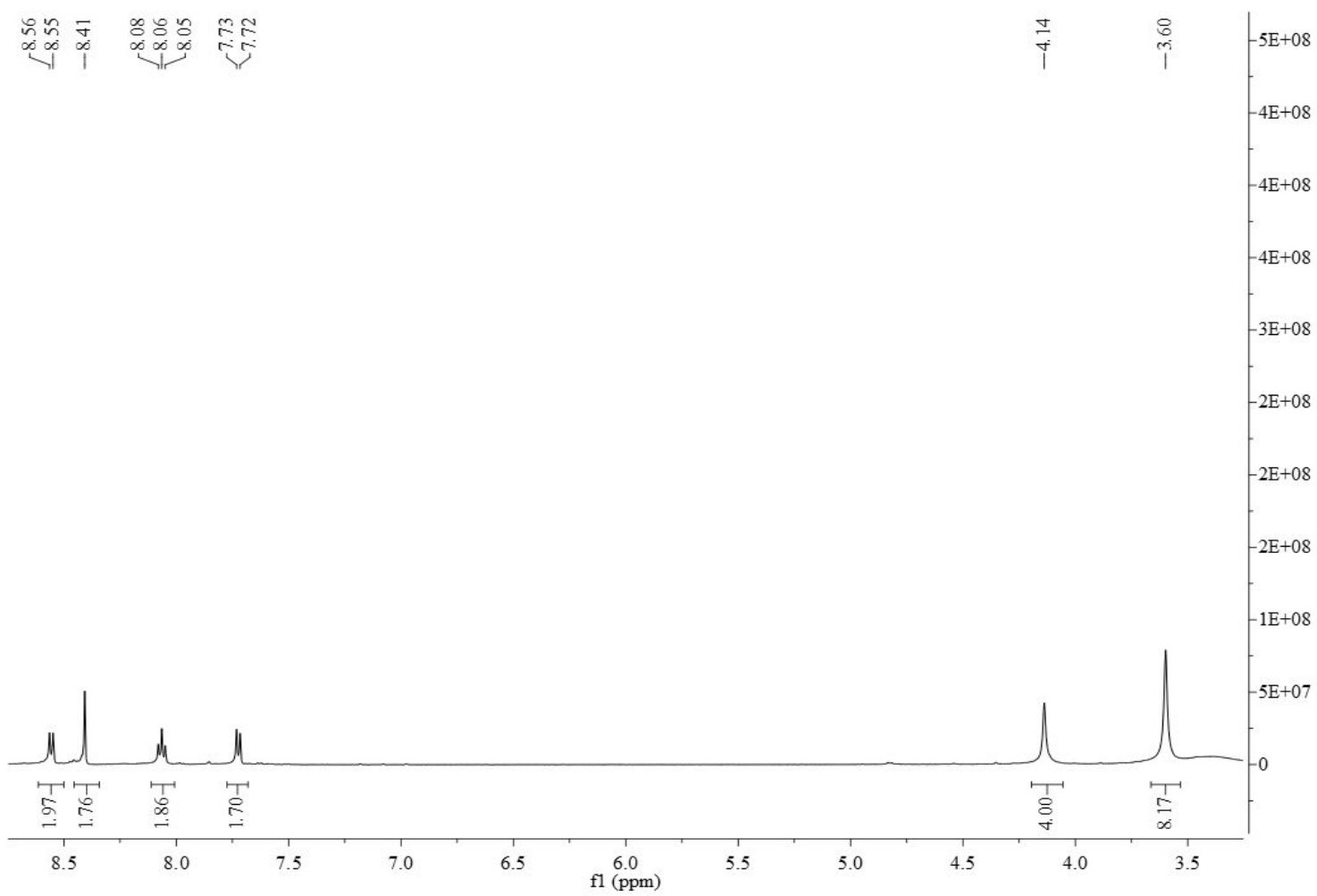

Figure S5. ${ }^{1} \mathrm{H}$ NMR spectrum of NFTTA $\left(D_{M S O}-d_{6}\right)$. 


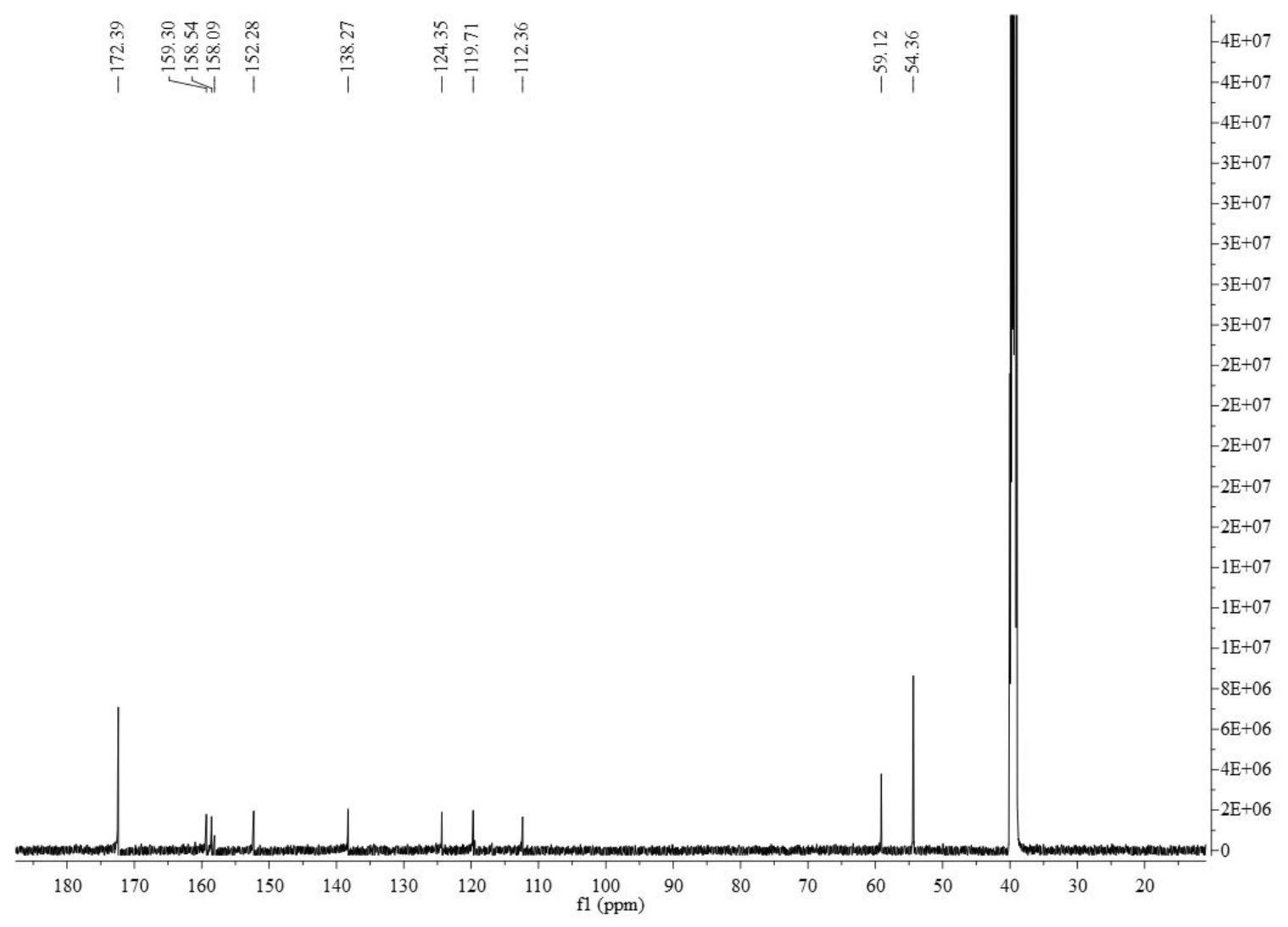

Figure S6. ${ }^{13} \mathrm{C}$ NMR spectrum of NFTTA $\left(\mathrm{DMSO}_{-} \mathrm{d}_{6}\right)$.

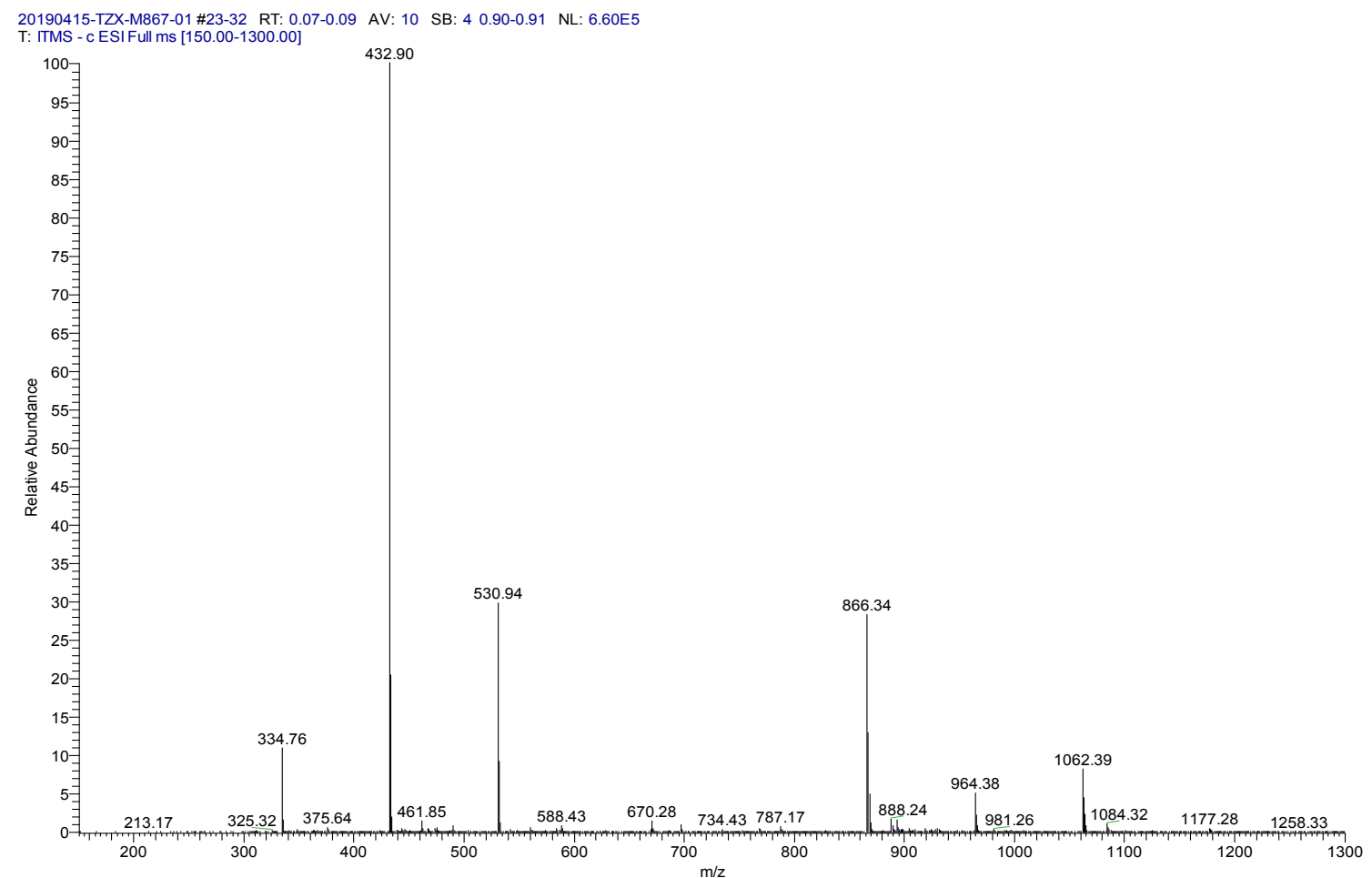

Figure S7. ESI-MS of ER-NFTTA. 


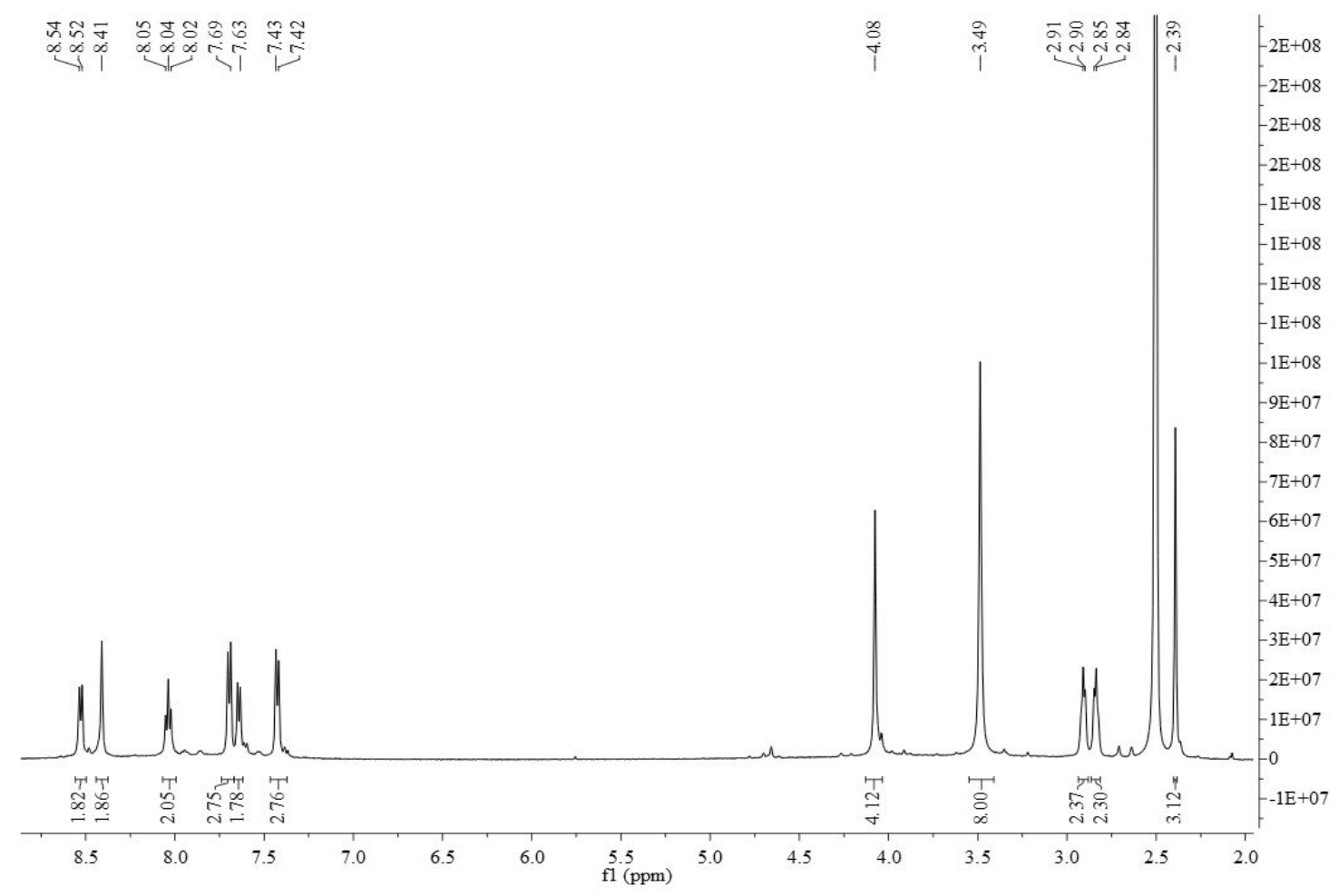

Figure S8. ${ }^{1} \mathrm{H}$ NMR spectrum of ER-NFTTA (DMSO-d ${ }_{6}$ ).

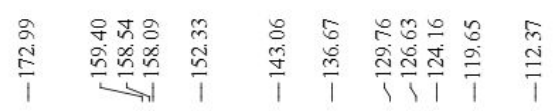

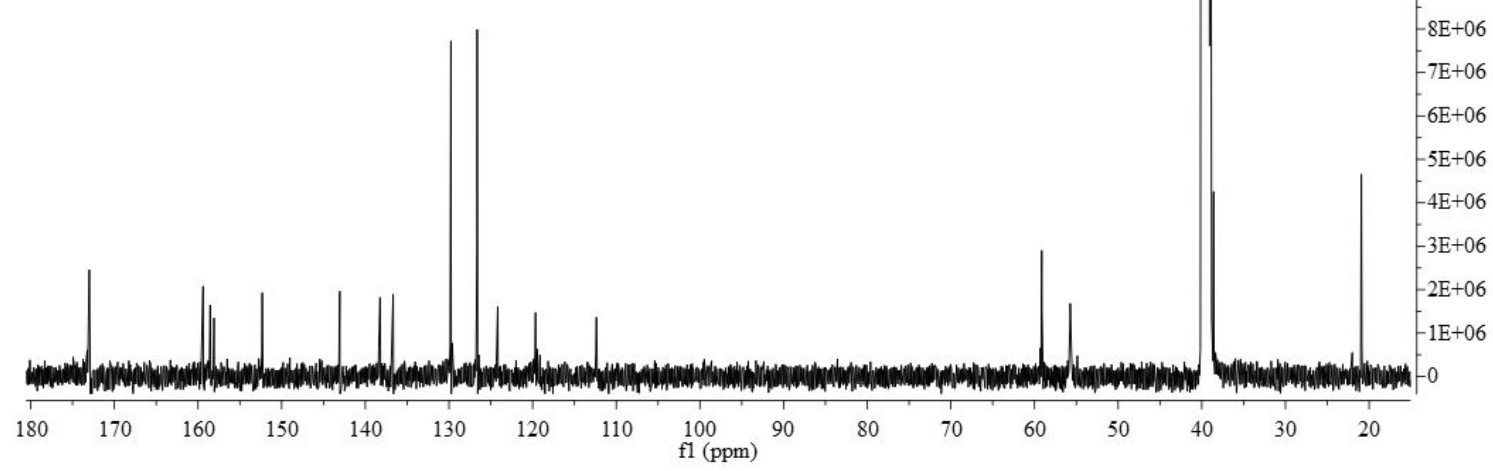

Figure S9. ${ }^{13} \mathrm{C}$ NMR spectrum of ER-NFTTA (DMSO-d $\left.{ }_{6}\right)$. 


\section{Characterization of the products of ER-NFTTA- $\mathrm{Ln}^{3+}$ reacted with $\mathrm{O}_{2}^{--}$}

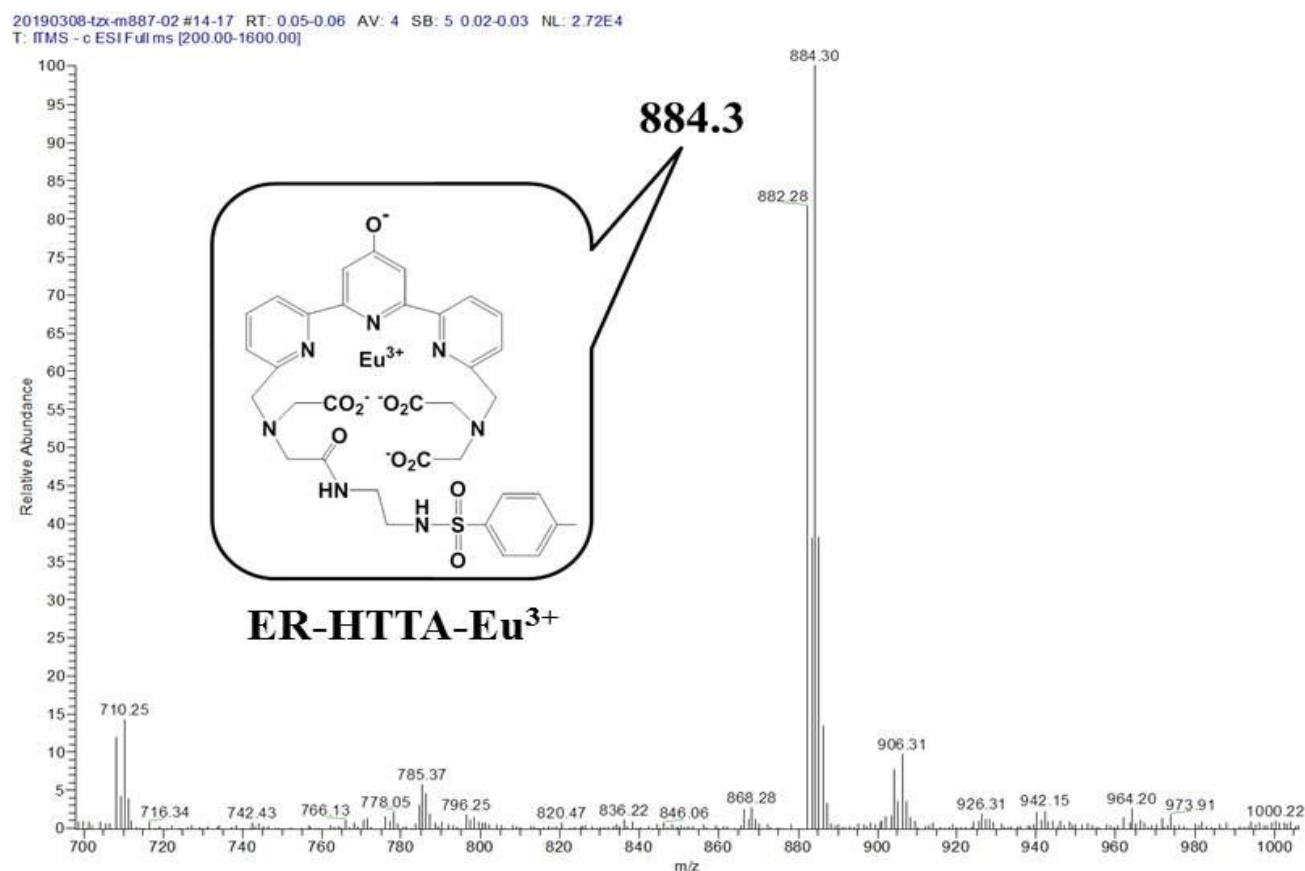

Figure S10. TOF-MS of the product of ER-NFTTA-Eu ${ }^{3+}$ reacted with $\mathrm{O}_{2}{ }^{--}$in $10 \mathrm{mM}$ PBS buffer of $\mathrm{pH} 7.4$.

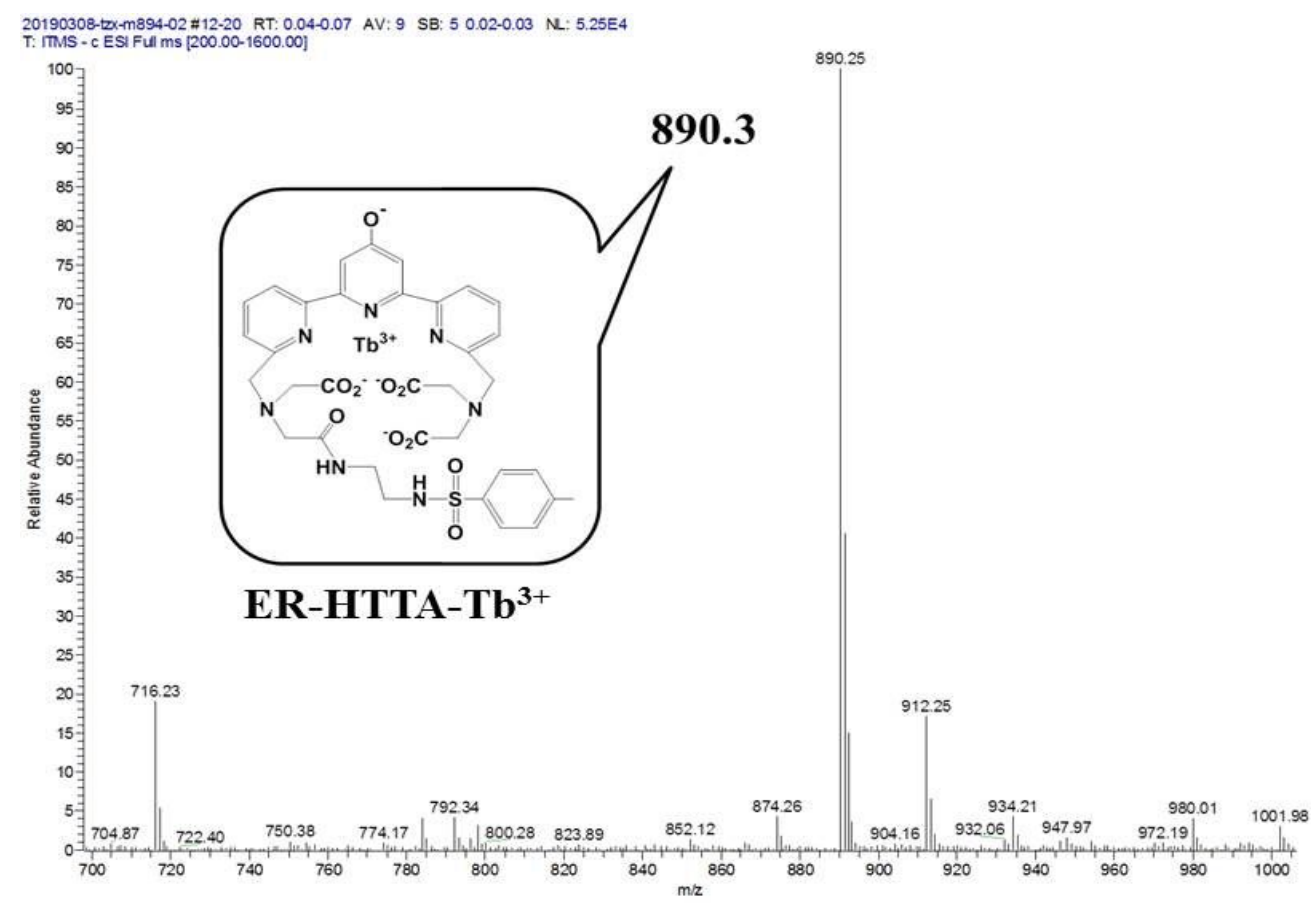

Figure S11. TOF-MS of the product of ER-NFTTA- $\mathrm{Tb}^{3+}$ reacted with $\mathrm{O}_{2}{ }^{--}$in $10 \mathrm{mM}$ PBS buffer of $\mathrm{pH} 7.4$. 

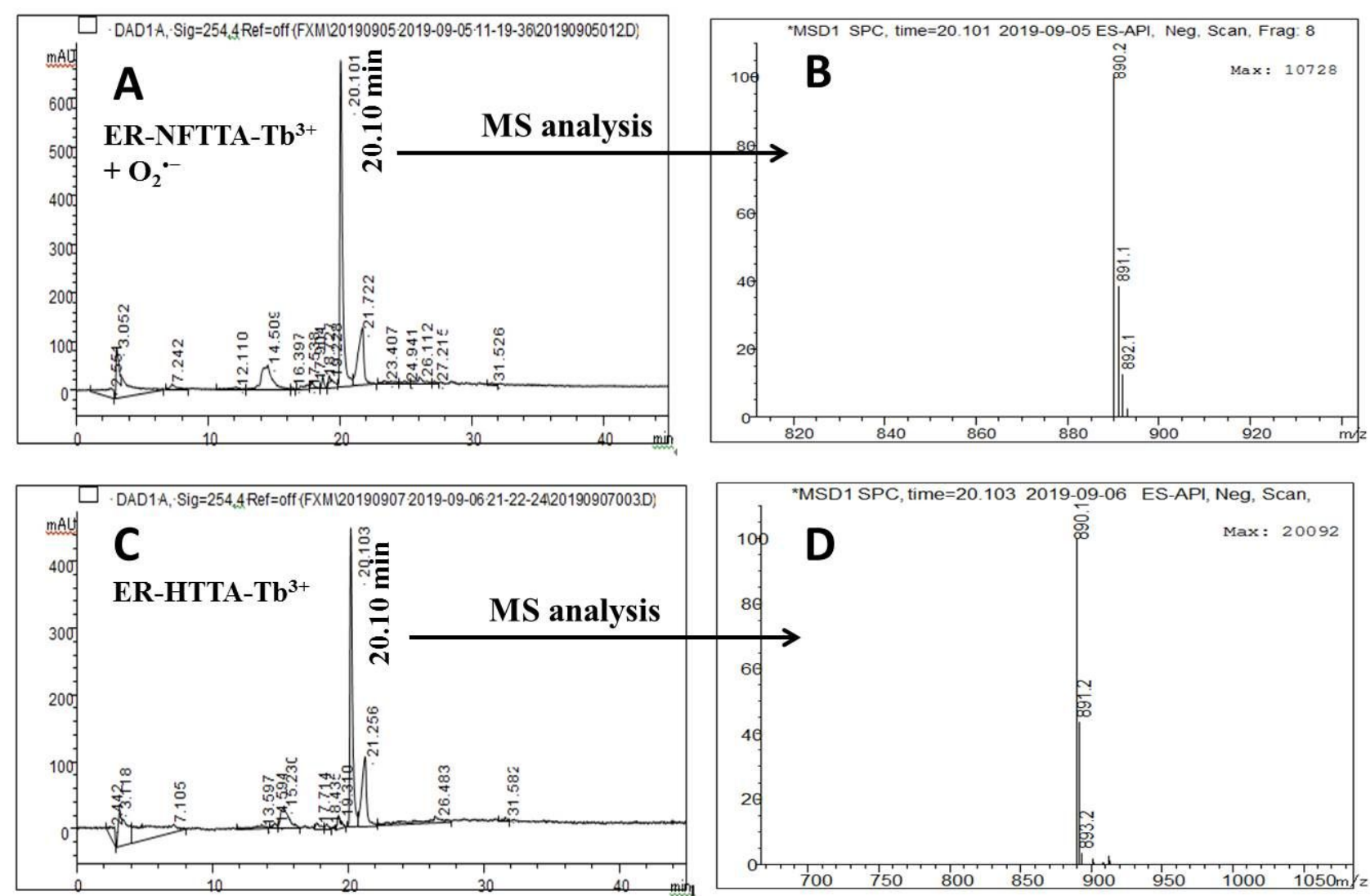

Figure S12. HPLC-MS analysis of the products of ER-NFTTA-Tb ${ }^{3+}$ reacted with $\mathrm{O}_{2}{ }^{--}(\mathrm{A}$ and B) and ER-HTTA-Tb ${ }^{3+}(\mathrm{C}$ and D). A and C: HPLC; B and D: ESI-MS.

\section{Effects of $\mathrm{pH}$ on luminescence response of the probe to $\mathrm{O}_{2}{ }^{--}$}

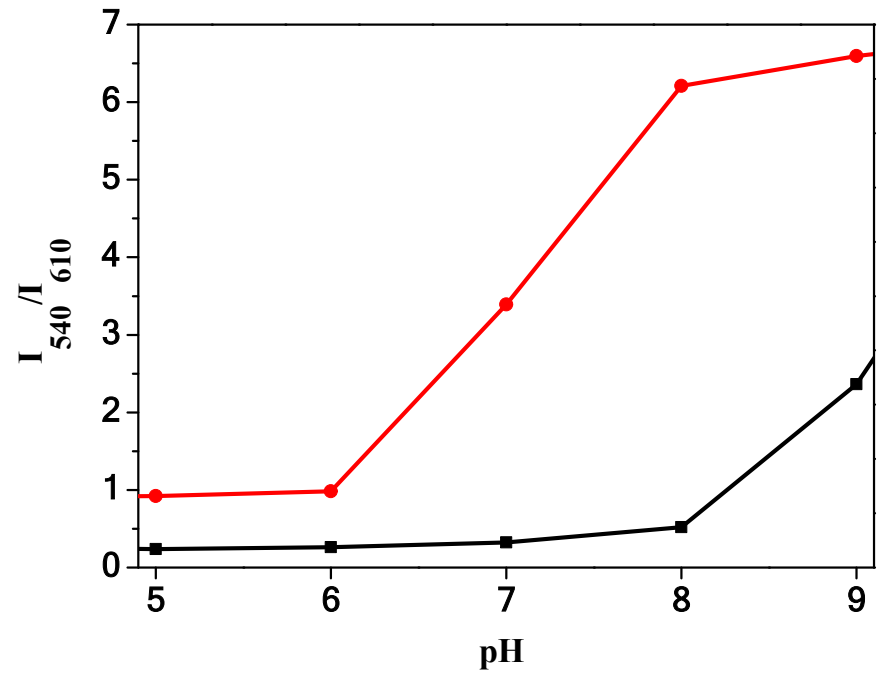

Figure S13. Effects of $\mathrm{pH}$ on the $\mathrm{I}_{540} / \mathrm{I}_{610}$ ratio of ER-NFTTA-Eu ${ }^{3+} / \mathrm{Tb}^{3+}\left(\mathrm{ER}-\mathrm{NFTTA} / \mathrm{Eu}^{3+} / \mathrm{Tb}^{3+}=\right.$ $2 / 1 / 1, \mathrm{C}_{\text {total }}=5.0 \mu \mathrm{M}$ ) in the absence (black line) and presence (red line) of $\mathrm{O}_{2}{ }^{--}$. 


\section{RTGL imaging of $\mathrm{O}_{2}^{--}$in live cells}

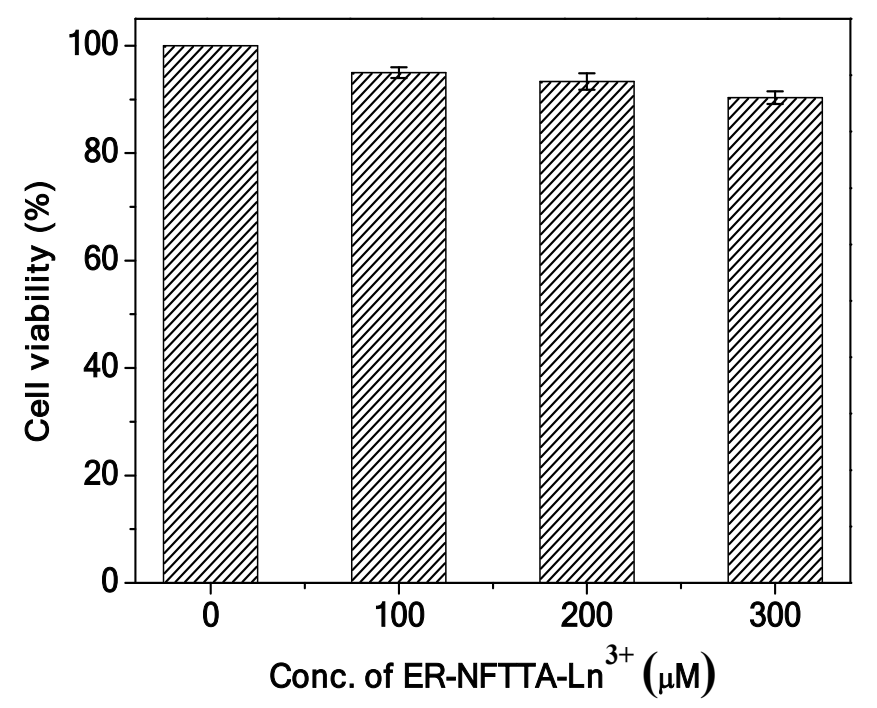

Figure S14. Viabilities of HepG2 cells incubated with different concentrations of ER-NFTTA-Eu ${ }^{3+} / \mathrm{Tb}^{3+}$ for $24 \mathrm{~h}$.
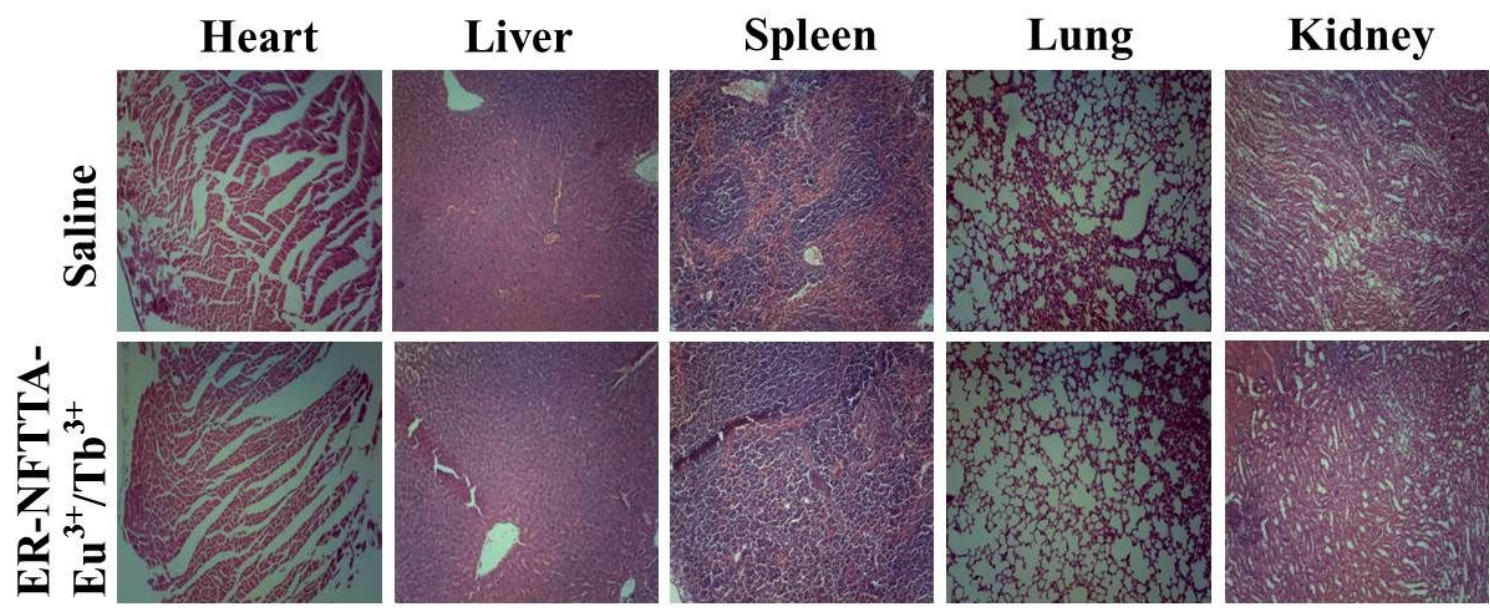

Figure S15. Images of H\&E stained main organs of the mice intravenously injected with saline and ER-NFTTA-Eu ${ }^{3+} / \mathrm{Tb}^{3+}(100 \mu \mathrm{L}$ in physiological saline, $500 \mu \mathrm{M})$ for $24 \mathrm{~h}$. 

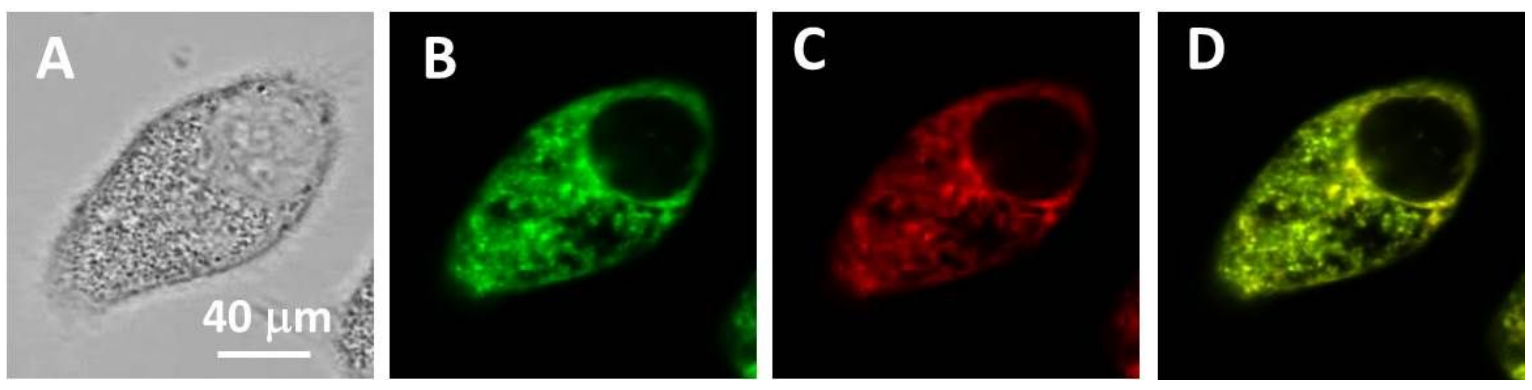

Figure S16. Intracellular co-localization analysis of ER-NFTTA-Tb ${ }^{3+}$ and ER-Tracker Red in a single live HepG2 cell. (A) Bright-field image of the cell. (B and C) Confocal fluorescence images of tunicamycin-treated cell incubated with ER-NFTTA-Tb ${ }^{3+}$ and further stained with ER-Tracker Red (B: channel 1, $\lambda_{\mathrm{ex}}=405 \mathrm{~nm}, \lambda_{\mathrm{em}}=520-570 \mathrm{~nm}$; $\mathrm{C}$ : channel $2, \lambda_{\mathrm{ex}}=559 \mathrm{~nm}, \lambda_{\mathrm{em}}=600-660$ nm). (D) Merged image of B and C.

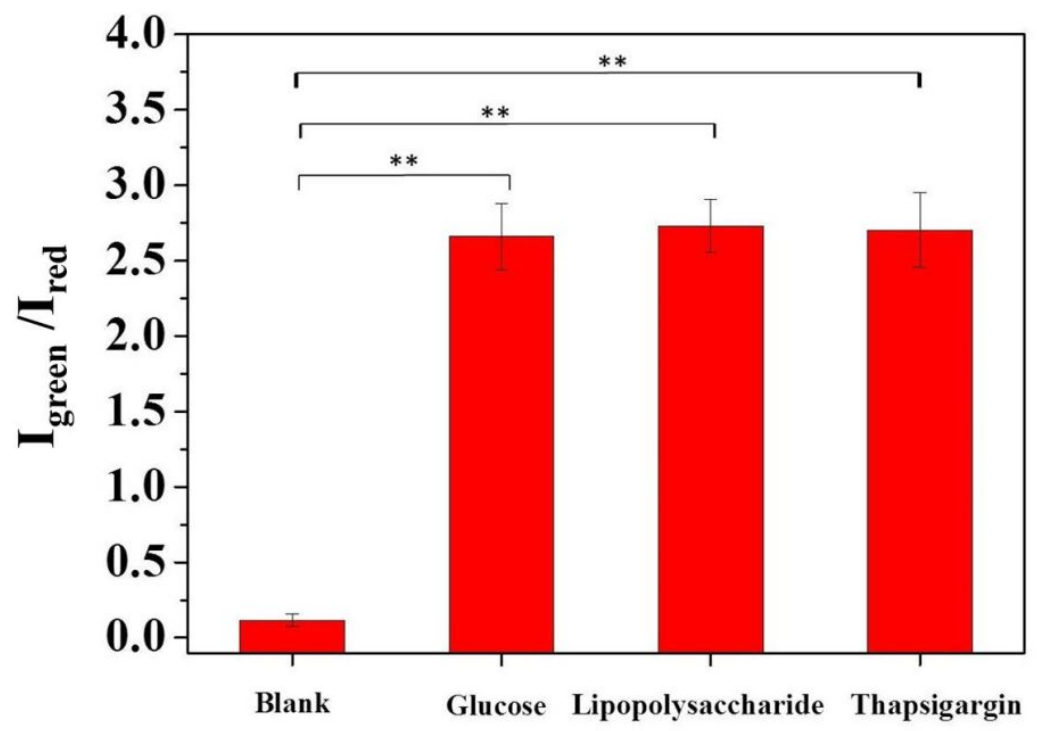

Figure S17. Average $\mathrm{I}_{\text {green }} / \mathrm{I}_{\text {red }}$ values of the cells in the ratiometric images of Figure $3(* * P<0.01)$. 


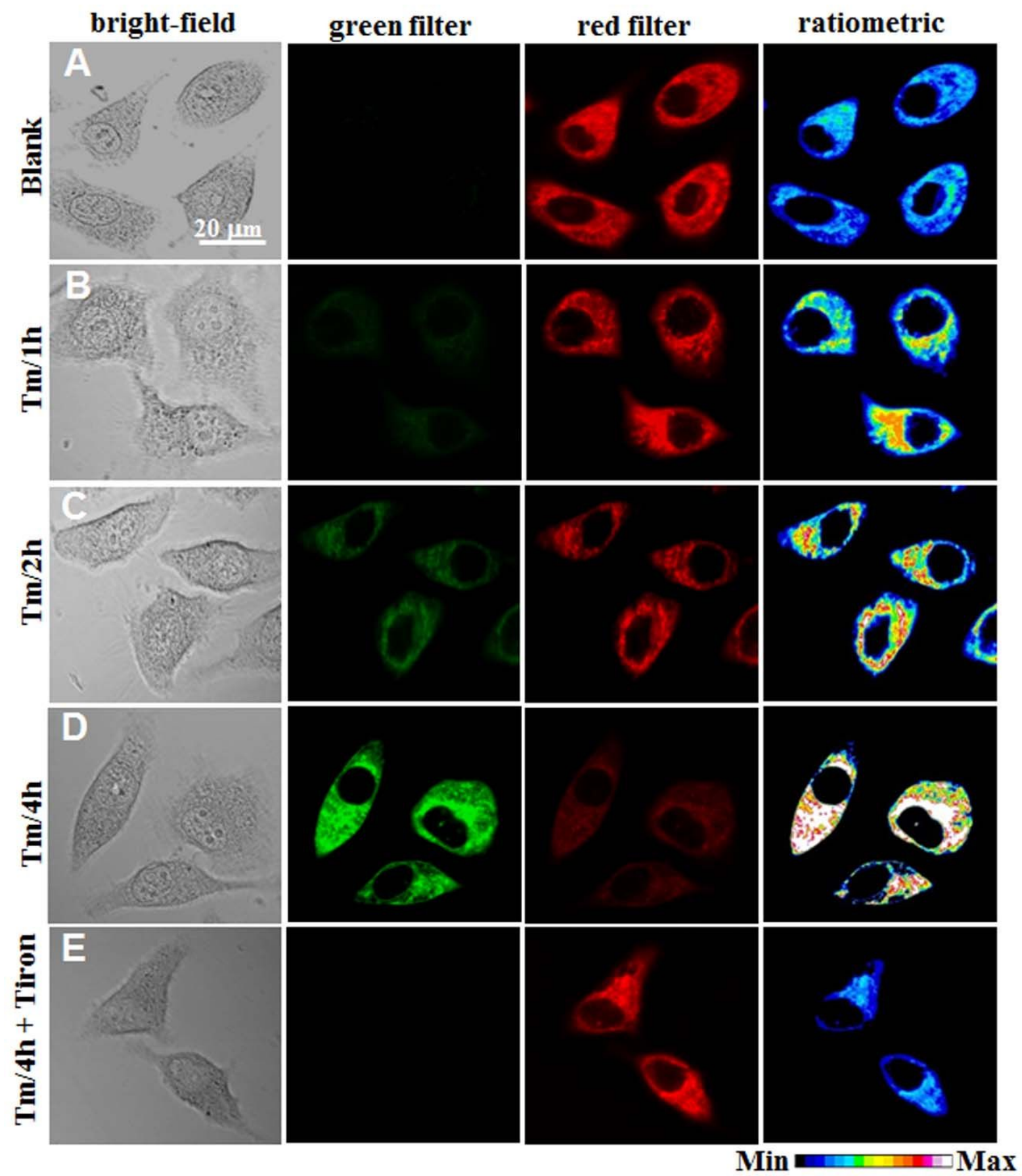

Figure S18. RTGL images of endogenously produced $\mathrm{O}_{2}{ }^{--}$in HepG2 cells via tunicamycin (Tm, $100 \mu \mathrm{g} / \mathrm{mL})$-stimulation using ER-NFTTA-Eu ${ }^{3+} / \mathrm{Tb}^{3+}\left(\right.$ ER-NFTTA/Eu ${ }^{3+} / \mathrm{Tb}^{3+}=2 / 1 / 1, \mathrm{C}_{\text {total }}=100$ $\mu \mathrm{M}$ ) as a probe. (A-D) The cells were pretreated with Tm for $0,1,2$ and $4 \mathrm{~h}$, respectively, and then incubated with the probe for $2 \mathrm{~h}$. (E) The cells were pretreated with Tm for $4 \mathrm{~h}$, further treated with tiron $(200 \mu \mathrm{M})$ for $4 \mathrm{~h}$, and then incubated with the probe for $2 \mathrm{~h}$. Green filter: $540 \pm 25 \mathrm{~nm}$; red filter: $>590 \mathrm{~nm}$; ratiometric: $\mathrm{I}_{\text {green }} / \mathrm{I}_{\text {red }}$. 


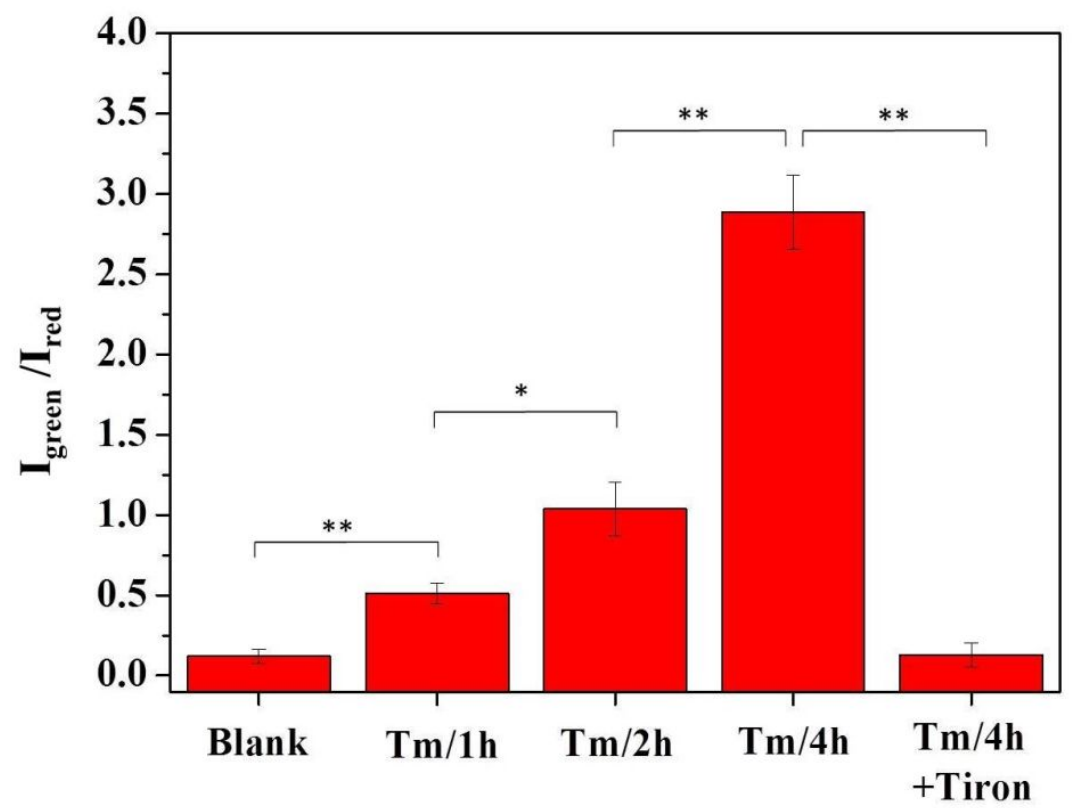

Figure S19. Average $\mathrm{I}_{\text {green }} / \mathrm{I}_{\text {red }}$ values of the cells in the ratiometric images of Figure $\mathrm{S} 18(* P<0.05$, $* * P<0.01)$.

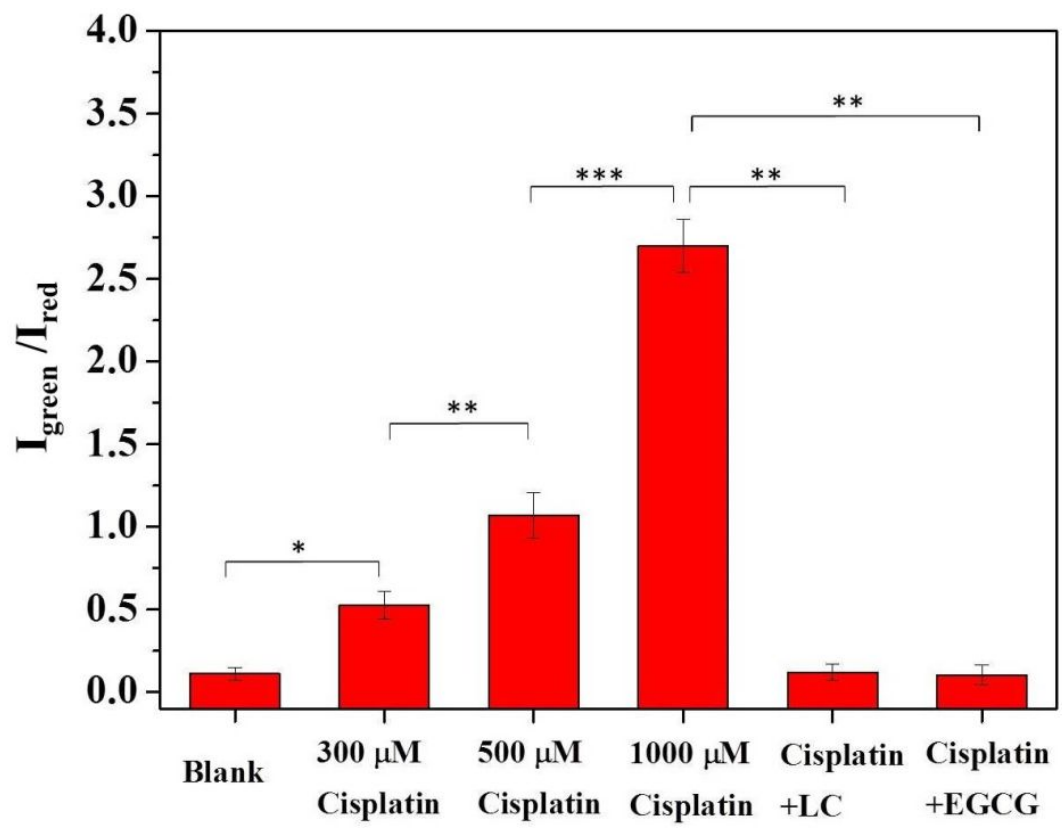

Figure S20. Average $I_{\text {green }} / I_{\text {red }}$ values of the HK-2 cells in the ratiometric images of Figure 4 $(* P<0.05, * * P<0.01, * * * P<0.001)$. 
6. Ratiometric luminescence imaging of $\mathrm{O}_{2}^{--}$in drug-induced nephrotoxicity in mouse kidney

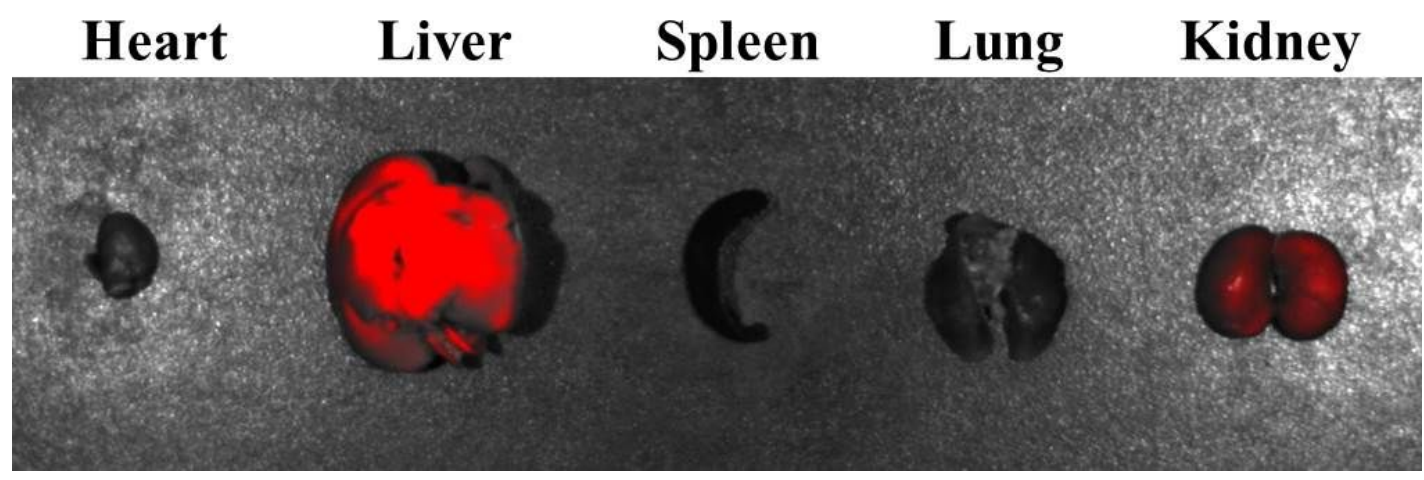

Figure S21. Ex vivo luminescence images of resected organs of the mice after intravenous injection of ER-NFTTA-Eu ${ }^{3+}(100 \mu \mathrm{L}$ in physiological saline,, $500 \mu \mathrm{M})$ for $2 \mathrm{~h}$.

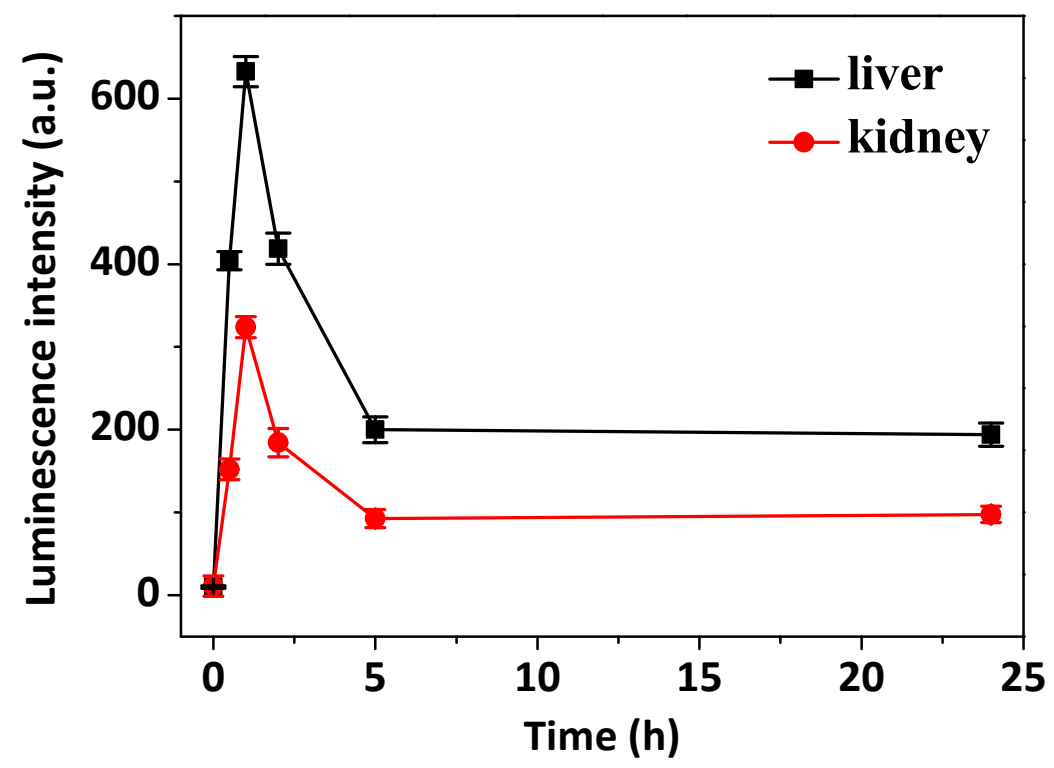

Figure S22. Mean luminescence intensities in livers and kidneys of mice after tail vein injection of ER-NFTTA-Eu ${ }^{3+}(100 \mu \mathrm{L}$ in physiological saline, $500 \mu \mathrm{M})$ for different times. 

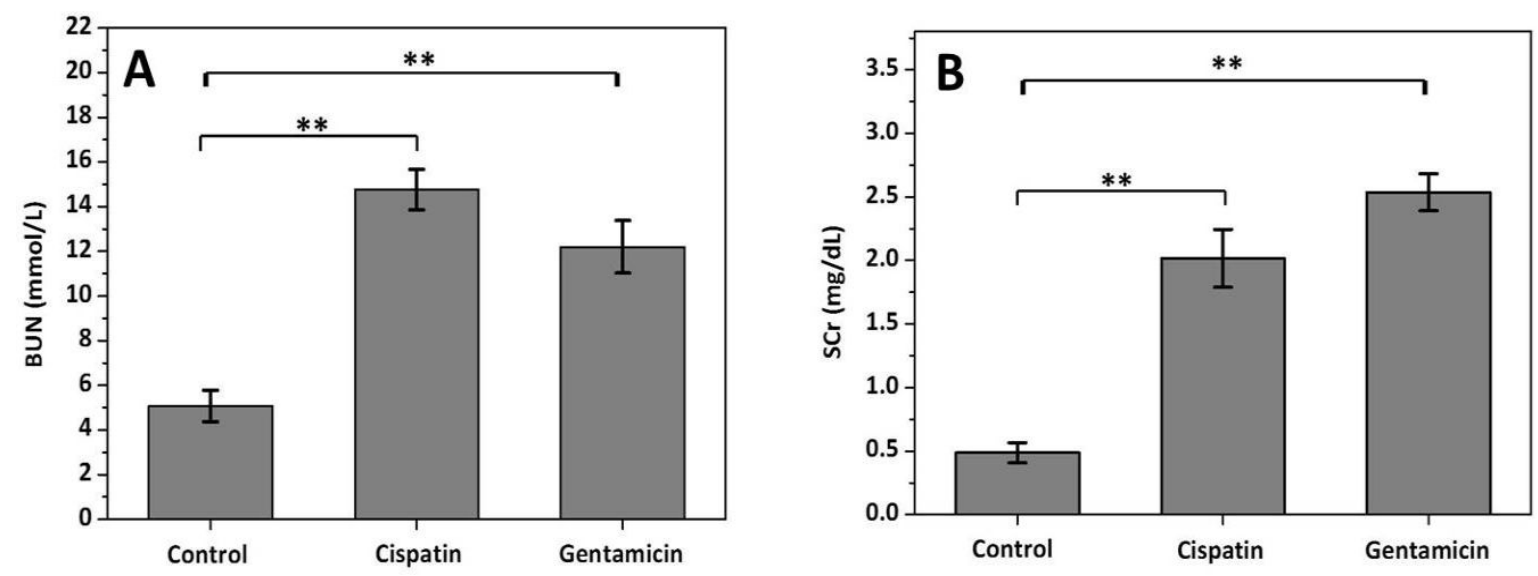

Figure S23. The concentrations of (A) blood urea nitrogen (BUN) and (B) serum creatinine (SCr) in normal (control) and drug-induced acute kidney injury of mice $(* * P<0.01)$.

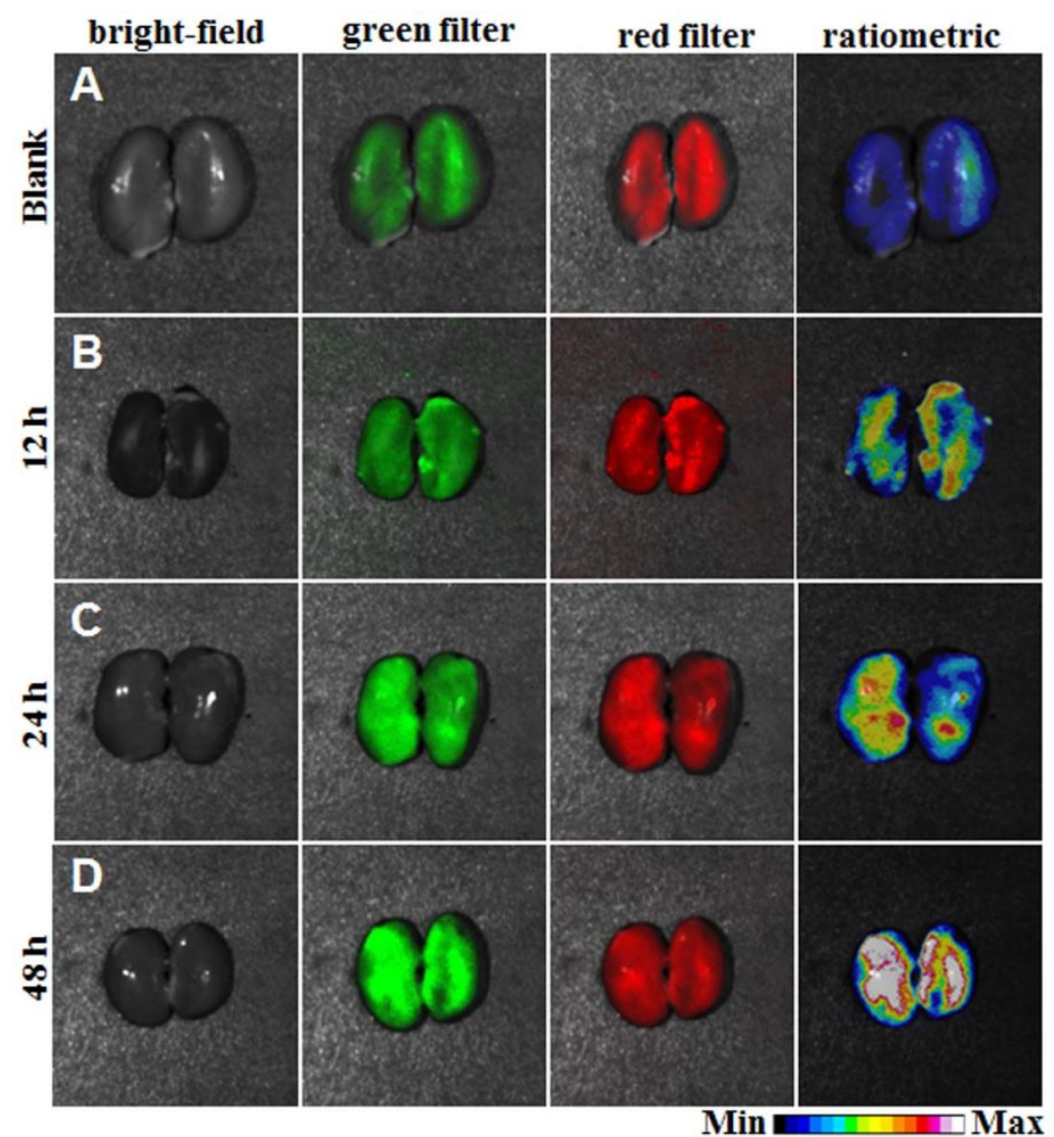

Figure S24. Ratiometric luminescence images of endogenously produced $\mathrm{O}_{2}{ }^{--}$in kidneys of mice injected intraperitoneally with cisplatin $(300 \mu \mathrm{L}, 20 \mathrm{mg} / \mathrm{kg})$ for different times $(\mathrm{A}: 0 \mathrm{~h}, \mathrm{~B}: 12 \mathrm{~h}, \mathrm{C}$ : $24 \mathrm{~h}, \mathrm{D}: 48 \mathrm{~h})$ and then intravenously injected with ER-NFTTA-Eu ${ }^{3+} / \mathrm{Tb}^{3+}(100 \mu \mathrm{L}, 500 \mu \mathrm{M})$ for 2 h. Green filter: $525 \pm 50 \mathrm{~nm}$; red filter: $630 \pm 75 \mathrm{~nm}$; ratiometric: $\mathrm{I}_{\text {green }} / \mathrm{I}_{\text {red. }}$. 


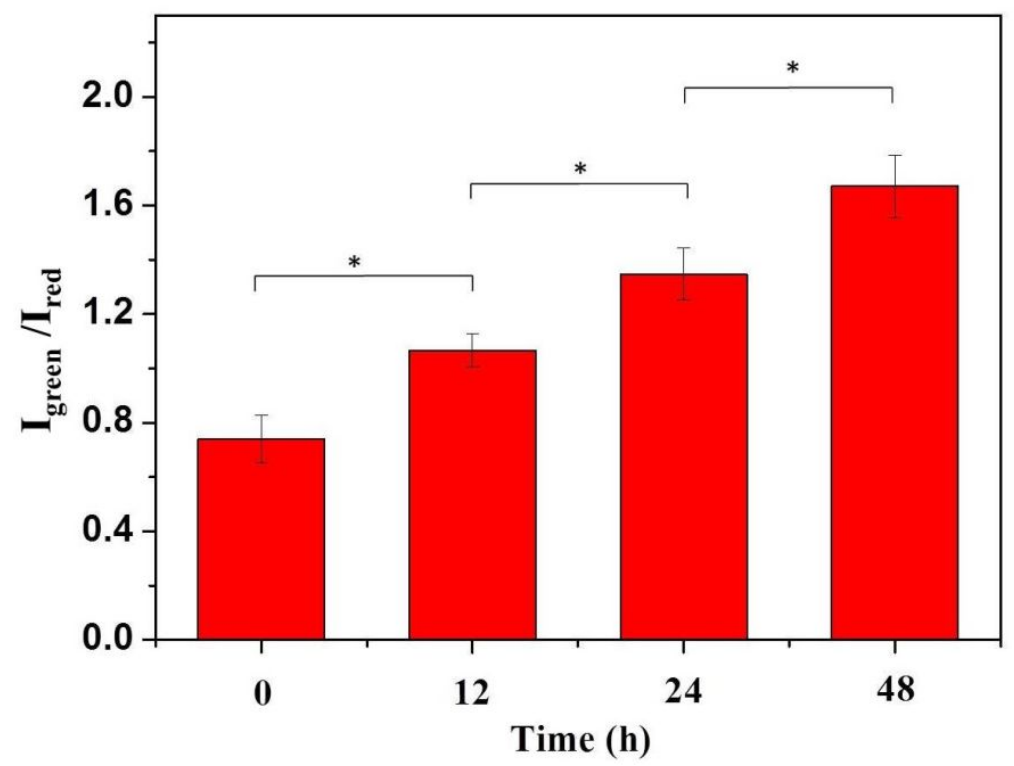

Figure S25. Average $\mathrm{I}_{\text {green }} / \mathrm{I}_{\text {red }}$ values of kidneys in the ratiometric images of Figure $\mathrm{S} 24(* P<0.05)$.

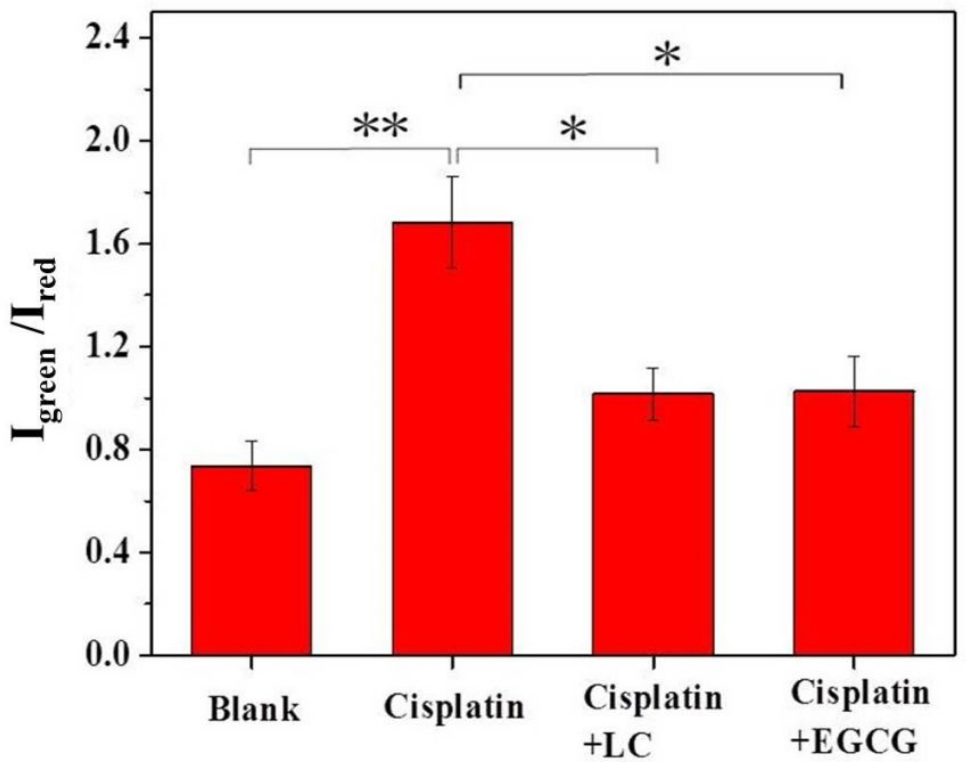

Figure S26. Average $\mathrm{I}_{\text {green }} / \mathrm{I}_{\text {red }}$ values of kidneys in the ratiometric images of Figure $5 \mathrm{~A}\left({ }^{*} P<0.05\right.$, $* * P<0.01)$. 


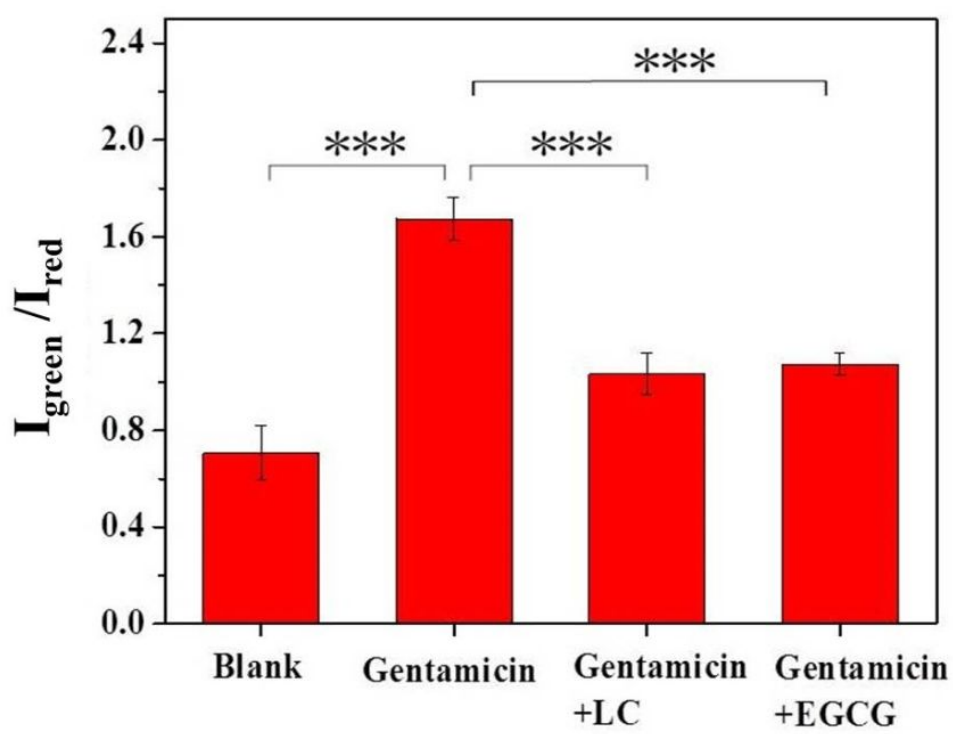

Figure S27. Average $I_{\text {green }} / I_{\text {red }}$ values of kidneys in the ratiometric images of Figure $5 \mathrm{C}$ $(* * * P<0.001)$.

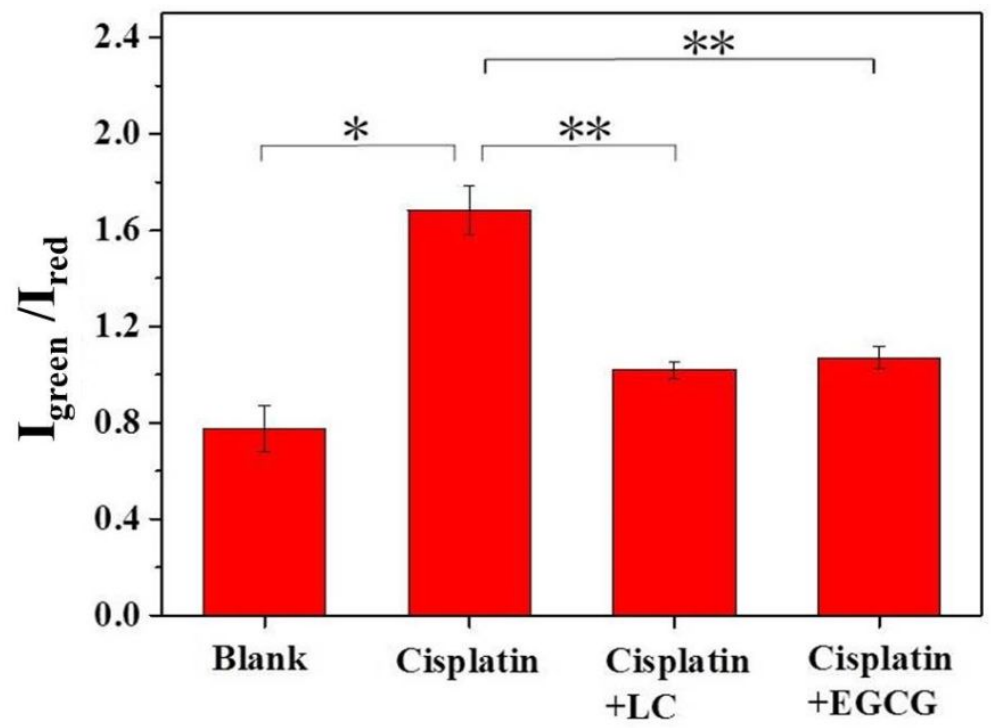

Figure S28. Average $\mathrm{I}_{\mathrm{green}} / \mathrm{I}_{\mathrm{red}}$ values in the RTGL images of kidney tissue slices (Figure 5B) $\left({ }^{*} P<0.05,{ }^{* *} P<0.01\right)$. 


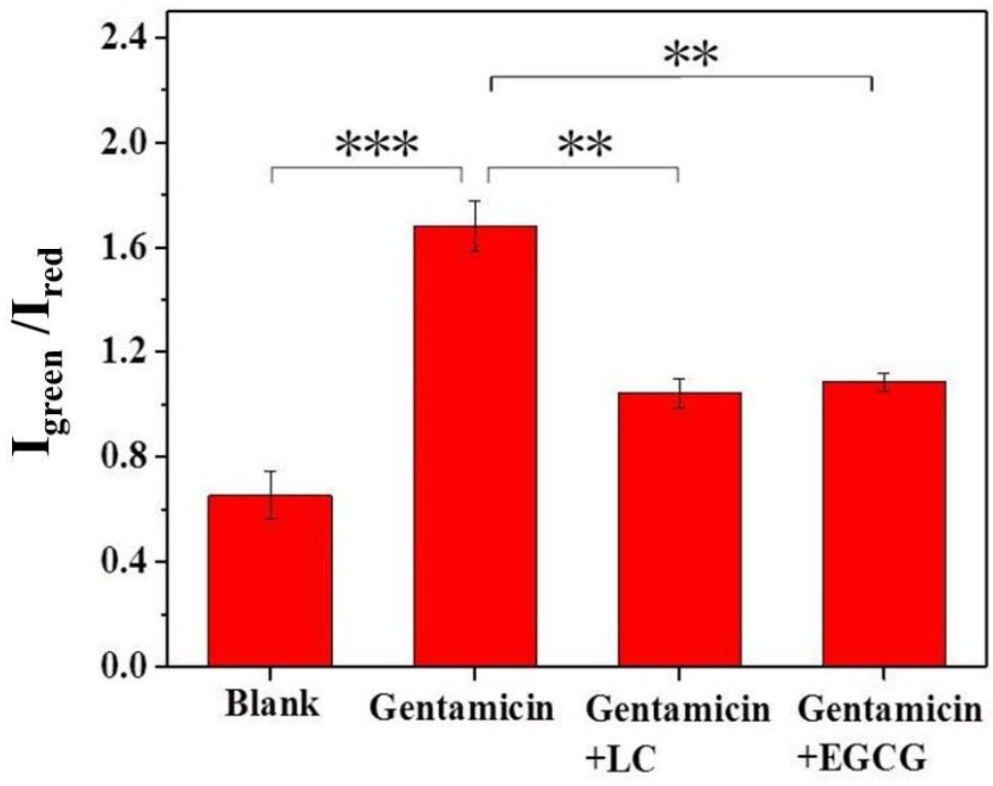

Figure S29. Average $I_{\text {green }} / I_{\text {red }}$ values in the RTGL images of kidney tissue slices (Figure 5D) $(* * P<0.01, * * * P<0.001)$.

\section{References}

1. Dai, Z.; Tian, L.; Ye, Z.; Song, B.; Zhang, R.; Yuan, J. A Lanthanide Complex-Based Ratiometric Luminescence Probe for Time-Gated Luminescence Detection of Intracellular Thiols. Anal. Chem. 2013, 85, 11658-11664.

2. Li, S. J.; Zhou, D. Y.; Li, Y.; Liu, H. W.; Wu, P.; Ou-Yang, J.; Jiang W. L.; Li, C. Y. Efficient two-photon fluorescent probe for imaging of nitric oxide during endoplasmic reticulum stress $A C S$ Sens., 2018, 3, 2311-2319.

3. Zhang, L.; Zheng, X.; Deng, W.; Lu, Y.; Lechevallier, S.; Ye, Z.; Goldys, E. M.; Dawes, J. M.; Piper, J. A.; Yuan, J.; Verelst, M.; Jin, D. Practical implementation, characterization and applications of a multi-colour time-gated luminescence microscope. Sci. Rep. 2014, 4, 6597.

4. Liu, M.; Ye, Z.; Xin, C.; Yuan, J. Development of a ratiometric time-resolved luminescence sensor for pH based on lanthanide complexes. Anal. Chim. Acta 2013, 761, 149-156.

5. Schatzschneider, U.; Niesel, J.; Ott, I.; Gust, R.; Alborzinia, H.; Wölfl, S. Cellular Uptake, Cytotoxicity, and Metabolic Profiling of Human Cancer Cells Treated with Ruthenium(II) Polypyridyl Complexes $\left[\mathrm{Ru}(\mathrm{BPY})_{2}\left(\mathrm{~N}^{\wedge} \mathrm{N}\right)\right] \mathrm{Cl}_{2}$ with $\mathrm{N}^{\wedge} \mathrm{N}=\mathrm{BPY}$, Phen, Dpq, Dppz, and Dppn. ChemMedChem. 2008, 3, 1104-1109. 